University of New Hampshire

University of New Hampshire Scholars' Repository

\title{
Northeast Bathymetry and Backscatter Compilation: Western Gulf of Maine, Southern New England, and Long Island Sound
}

\author{
Larry G. Ward \\ University of New Hampshire, Igward@ad.unh.edu \\ Paul Johnson \\ University of New Hampshire, pjohnson@ccom.unh.edu \\ Michael Bogonko \\ University of New Hampshire, mbogonko@ccom.unh.edu \\ Zachary S. McAvoy \\ University of New Hampshire, Zachary.McAvoy@unh.edu \\ Rachel C. Morrison \\ University of New Hampshire, rmorrison@ccom.unh.edu
}

Follow this and additional works at: https://scholars.unh.edu/ccom

Part of the Oceanography Commons

\section{Recommended Citation \\ Ward, L.G., Johnson, P., Bogonko, M., McAvoy, Z.S., and Morrison, R.C., 2021, Northeast Bathymetry and Backscatter Compilation: Western Gulf of Maine, Southern New England, and Long Island Sound: BOEM/ New Hampshire Cooperative Agreement (Contract M14AC00010) Technical Report, Department of Interior, Bureau of Ocean Energy Management, Marine Minerals Division, 45600 Woodland Road, Sterling, VA, 20166., 23 pp. https://dx.doi.org/10.34051/p/2021.28}

This Report is brought to you for free and open access by the Center for Coastal and Ocean Mapping at University of New Hampshire Scholars' Repository. It has been accepted for inclusion in Center for Coastal and Ocean Mapping by an authorized administrator of University of New Hampshire Scholars' Repository. For more information, please contact Scholarly.Communication@unh.edu. 


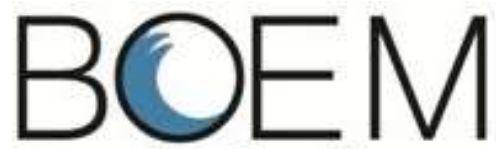

Bureau of Ocean Energy Management

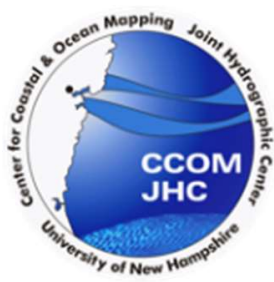

BOEM/New Hampshire Cooperative Agreement (Contract M14ACO0010) Technical Report

\section{Northeast Bathymetry and Backscatter Compilation: Western Gulf of Maine, Southern New England, and Long Island}

By Ward, L.G., Johnson, P., Bogonko, M., McAvoy, Z.S., and Morrison, R.C.

University of New Hampshire Center for Coastal and Ocean Mapping/Joint Hydrographic Center 24 Colovos Road, Durham, NH 03824

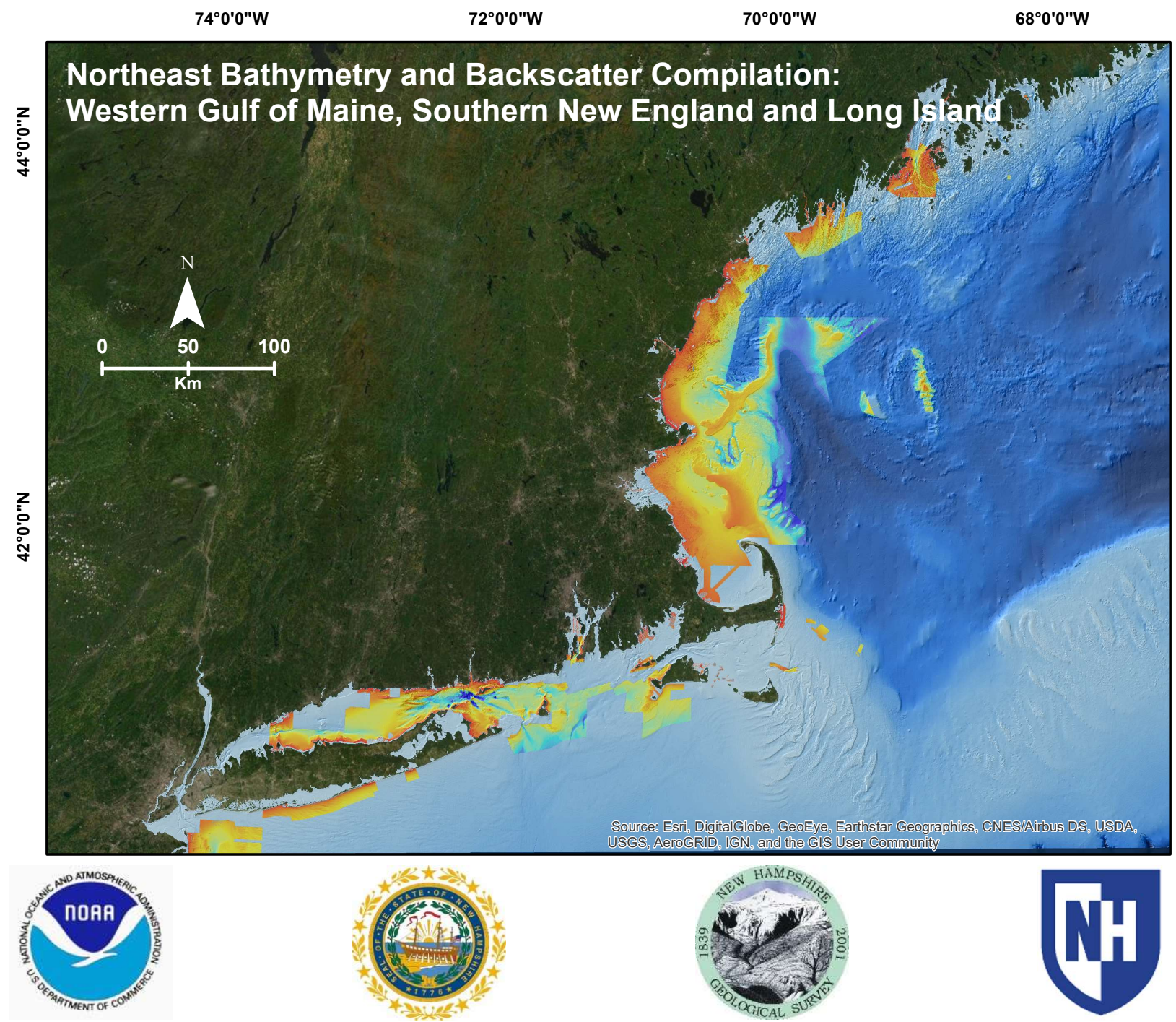




\section{Acknowledgements}

The development of the Northeast Bathymetry and Backscatter Compilation: Western Gulf of Maine, Southern New England, and Long Island Sound was supported by the Bureau of Ocean Energy Management Award Number M14AC00010 and University of New Hampshire/National Oceanic and Atmospheric Administration Joint Hydrographic Center Award Number NA10NOS4000073.

We gratefully acknowledge NOAA National Ocean Service (NOS) for providing hydrographic and backscatter survey data. Will Fessenden (IT) and Colleen Mitchell (Graphic Design and Editing) provided valuable technical advice and support. A number of colleagues at the University of New Hampshire Center for Coastal and Ocean Mapping (CCOM) and Joint Hydrographic Center (JHC) provided scientific advice and insight including Semme Dijkstra, Larry Mayer, and Giuseppe Masetti. We would also like to acknowledge the input and advice of colleagues from NOS Office of Coast Survey (OCS) and JHC including Andrew Armstrong, Juliet Kinney, Erin Nagel, Glen Rice, and Katrina Wyllie.

\section{Map Coordinate System, Projection and Datum}

Coordinate System: WGS 1984 UTM Zone 19N

Projection: Transverse Mercator

Horizontal Datum: WGS 1984

Vertical Datum: MLLW

\section{Website: Northeast Bathymetry and Backscatter Compilation: Western Gulf of Maine, Southern New England, and Long Island}

(https://maps.ccom.unh.edu/portal/apps/webappviewer/index.html?id=5d314116ad094afebbd02ffc18 5164f6); accessed June 1, 2021

\section{Recommended Citation}

Ward, L.G., Johnson, P., Bogonko, M., McAvoy, Z.S., and Morrison, R.C., 2021, Northeast Bathymetry and Backscatter Compilation: Western Gulf of Maine, Southern New England, and Long Island Sound: BOEM/New Hampshire Cooperative Agreement (Contract M14ACO0010) Technical Report, Department of Interior, Bureau of Ocean Energy Management, Marine Minerals Division, 45600 Woodland Road, Sterling, VA, 20166., 23 pp. https://dx.doi.org/10.34051/p/2021.28 


\section{Table of Contents}

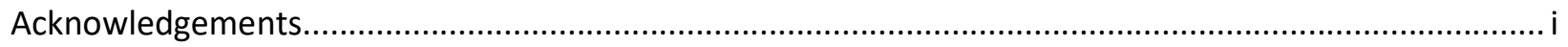

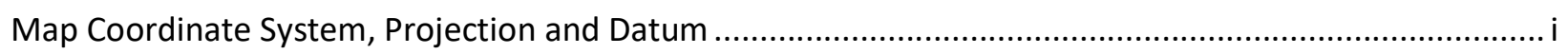

Website: Northeast Bathymetry and Backscatter Compilation: Western Gulf of Maine, Southern New

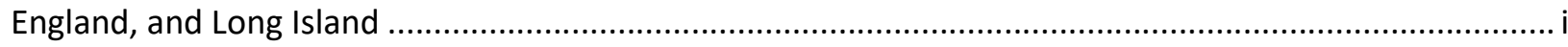

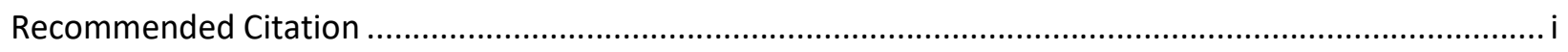

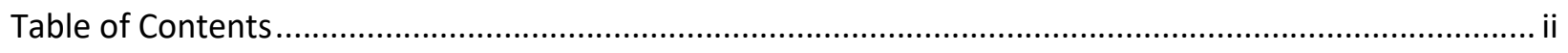

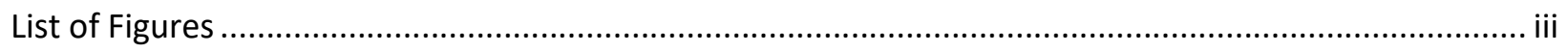

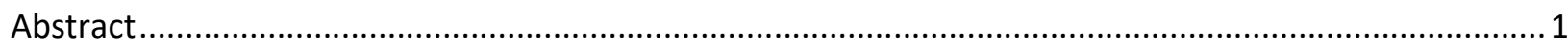

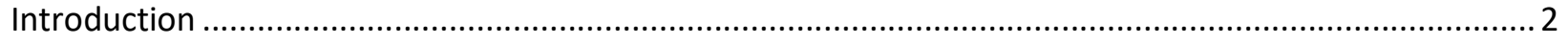

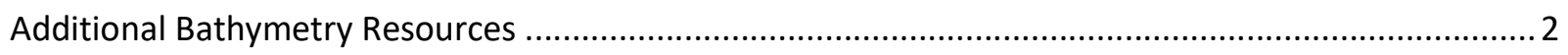

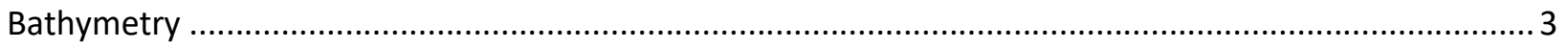

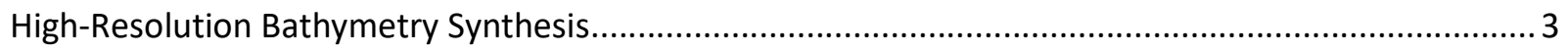

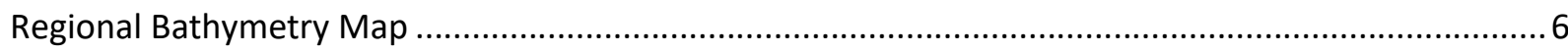

UNH CCOM/JHC High-Resolution Bathymetry and Backscatter Surveys............................................ 7

Multibeam Echosounder Backscatter Syntheses................................................................... 8

UNH CCOM/JHC WGOM Backscatter Synthesis ..........................................................................

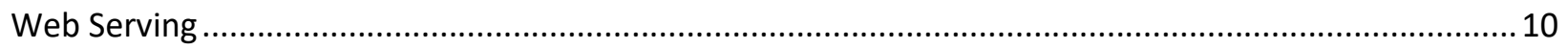

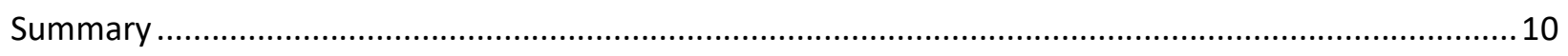

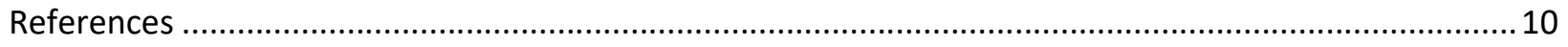

Appendix A: Metadata for bathymetry and backscatter surveys used for the Western Gulf of Maine..... 15

Appendix B: Metadata for bathymetry and backscatter surveys used for Southern New England and Long

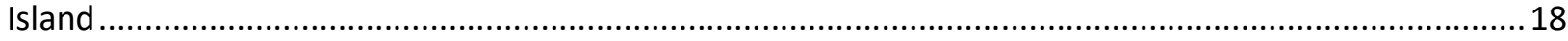




\section{List of Figures}

Figure 1. Multibeam echosounder surveys included in the "Northeast Bathymetry and Backscatter Compilation: Western Gulf of Maine, Southern New England, and Long Island".....

Figure 2. High-resolution bathymetry of the Western Gulf of Maine gridded at $4 \mathrm{~m}$. The vertical exaggeration is five

Figure 3. High-resolution bathymetry of Southern New England and Long Island Sound gridded at 4m.

The vertical exaggeration is five. 5

Figure 4. Regional bathymetry for the U.S. Northeast gridded at $16 \mathrm{~m}$. The vertical exaggeration is five... 6

Figure 5. UNH CCOM/JHC Hydrographic Field Course MBES surveys from the NH continental shelf. ........7

Figure 6. Backscatter mosaic developed by the USGS (see Pendleton et al., 2013). ............................... 8

Figure 7. UNH CCOM/JHC Backscatter Synthesis (WGOM Backscatter Synthesis) gridded at 2.0m........... 9

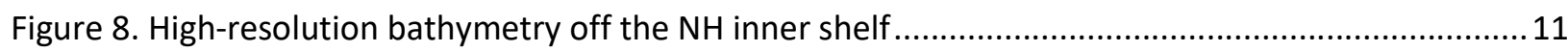

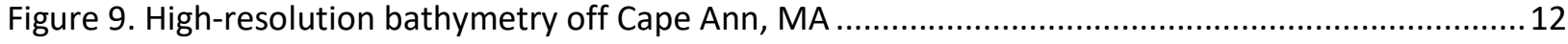

Figure 10. High-resolution bathymetry of the entrance to Long Island Sound ....................................13

Figure 11. High-resolution bathymetry of the entrance to Long Island Sound showing an enlargement of the narrows 


\section{Northeast Bathymetry and Backscatter Compilation: Western Gulf of Maine, Southern New England, and Long Island Sound}

By Ward, L.G., Johnson, P., Bogonko, M., McAvoy, Z.S., and Morrison, R.C. University of New Hampshire Center for Coastal and Ocean Mapping/Joint Hydrographic Center

\section{Abstract}

High-resolution bathymetry is critical for mapping the surficial geology of the seafloor, identifying critical habitats, and assessing marine mineral resources such as sand and gravel. In 2016, a high-resolution bathymetry map was developed for the western Gulf of Maine (WGOM) utilizing all available multibeam echosounder (MBES) surveys, as well as several older extant surveys (Western Gulf of Maine Bathymetry and Backscatter Synthesis, Ward et al., 2016). As part of that effort, a backscatter mosaic also was developed for a subset of the MBES surveys. The backscatter synthesis did not include all of the MBES surveys due to low quality of some of the mosaics and limitations of combining MBES backscatter surveys (e.g., different frequencies).

In order to extend the high-resolution bathymetry coverage of the U.S. Northeast (NE), the WGOM Bathymetry and Backscatter Synthesis was substantially expanded. A careful review of the available bathymetry and backscatter from Maine to New York was conducted and the needed databases obtained. In addition, bathymetric lidar surveys were gathered, primarily in the WGOM. Unfortunately, the MBES coverage was relatively sparse over large areas of the NE region with few surveys available for mid and northern Maine, south of Cape Cod, and along the Atlantic coast of Long Island to New York Harbor. However, relatively good coverage exists for Long Island Sound. Similarly, high quality backscatter mosaics co-registered with the bathymetry was sparse. Nevertheless, the available bathymetry and backscatter does allow a significant expansion of the overall coverage and exposes areas where more information would be beneficial. Some low-resolution bathymetry data (e.g., single beam surveys that leave gaps between survey lines) were also obtained but were only used in a Regional Bathymetry Map.

The "Northeast Bathymetry and Backscatter Compilation: Western Gulf of Maine, Southern New England, and Long Island Sound" expands the coverage of high-resolution MBES to include southern New England and Long Island Sound. The main bathymetry synthesis is gridded at $4 \mathrm{~m}, 8 \mathrm{~m}$, and $16 \mathrm{~m}$. Also included are MBES bathymetry surveys that provide more detail of regions where research projects have been conducted by the University of New Hampshire (UNH) Center for Coastal and Ocean Mapping/Joint Hydrographic Center (CCOM/JHC). The overall backscatter coverage for the WGOM inner continental shelf is presented as compilations and individual survey mosaics (UNH CCOM/JHC surveys). South of Cape Cod to New York Harbor the backscatter is limited and presented as individual surveys where available.

The "Northeast Bathymetry and Backscatter Compilation: Western Gulf of Maine, Southern New England, and Long Island Sound" can be viewed on the CCOM/JHC website at:

(https://maps.ccom.unh.edu/portal/apps/webappviewer/index.html?id=5d314116ad094afebbd02ffc18 5164f6); accessed June 1, 2021 


\section{Introduction}

The continental shelf off the northeastern United States from Maine to Long Island was shaped by interactions of riverine sediment inputs, glaciations, and sea-level fluctuations. To the north, the western Gulf of Maine (WGOM) is characterized by extensive bedrock outcrops, marine-modified glacial deposits, numerous bathymetric highs (e.g., Jeffreys Ledge, Cashes Ledge, Fippennies Ledge, Stellwagen Bank), and deep ocean basins (e.g., Jeffreys Basin, Wilkinson Basin). Further south from Cape Cod to Long Island, the shelf is composed of wide sandy plains and marine-modified glacial deposits. Here, the bottom can change rapidly due to storms and other high-energy events. As a result, the seafloor in the U.S. Northeast (NE) is extremely complex and can vary significantly over short distances or have extensive homogeneous regions. Fortunately, there have been a number of high-resolution multibeam echosounder (MBES) surveys in the WGOM off southern Maine, New Hampshire, and Massachusetts that provide excellent bathymetric coverage of the seafloor. The same is true for much of Long Island Sound. Unfortunately, MBES bathymetry coverage is much less dense in mid and northern Maine and south of Cape Cod to New York Harbor along the Atlantic Coast.

The "Northeast Bathymetry and Backscatter Compilation: Western Gulf of Maine, Southern New England, and Long Island" (hereafter referred to as the "Compilation") brings together the MBES surveys for the NE with the primary goal of presenting a synthesis of all high-resolution bathymetry in a single gridded surface accompanied by backscatter where available and of good quality (Figure 1). Also, a lower resolution regional synthesis is presented. The high-resolution bathymetry synthesis primarily consists of MBES surveys gridded at $4 \mathrm{~m}, 8 \mathrm{~m}$, and $16 \mathrm{~m}$. The regional bathymetry surface consists of single beam echosounder (SBES) and MBES surveys gridded at $16 \mathrm{~m}$. The backscatter mosaics include compilations for the inner shelf off New Hampshire (NH) by the University of New Hampshire (UNH) Center for Coastal and Ocean Mapping and Joint Hydrographic Center (CCOM/JHC), and for the Massachusetts coast north of Cape Cod by the United States Geological Survey (USGS). In addition, there are a number of individual MBES surveys presented.

The Compilation is a major expansion of the "Western Gulf of Maine Bathymetry and Backscatter Synthesis" published by CCOM/JHC in 2016 (Ward et al., 2016). The WGOM synthesis has been widely used by a number of federal and state agencies, as well as private individuals (e.g., the local fishing community). The purpose of expanding the bathymetry and backscatter synthesis and compilation is to provide a basis for future mapping of surficial geology and habitats in the NE, to support studies to identify marine minerals on the NE continental shelf, and to aid in conducting environmental studies if sand and gravel extraction is proposed.

\section{Additional Bathymetry Resources}

Other bathymetry compilations exist for the U.S. Northeast. Notable is a comprehensive compilation created by the National Ocean Survey (NOS) that compiles all bathymetry resources as they become available into the "National Bathymetry Source" (NBS). The NBS is frequently updated and merged into the bathymetry grid. The "Northeast Bathymetry and Backscatter Compilation: Western Gulf of Maine, Southern New England, and Long Island" presented here primarily focuses on high-resolution bathymetry and includes backscatter surveys.

For more information about the NBS go to https://nauticalcharts.noaa.gov/updates/building-thenational-bathymetry/. For questions contact ocs.nbs@noaa.gov. 


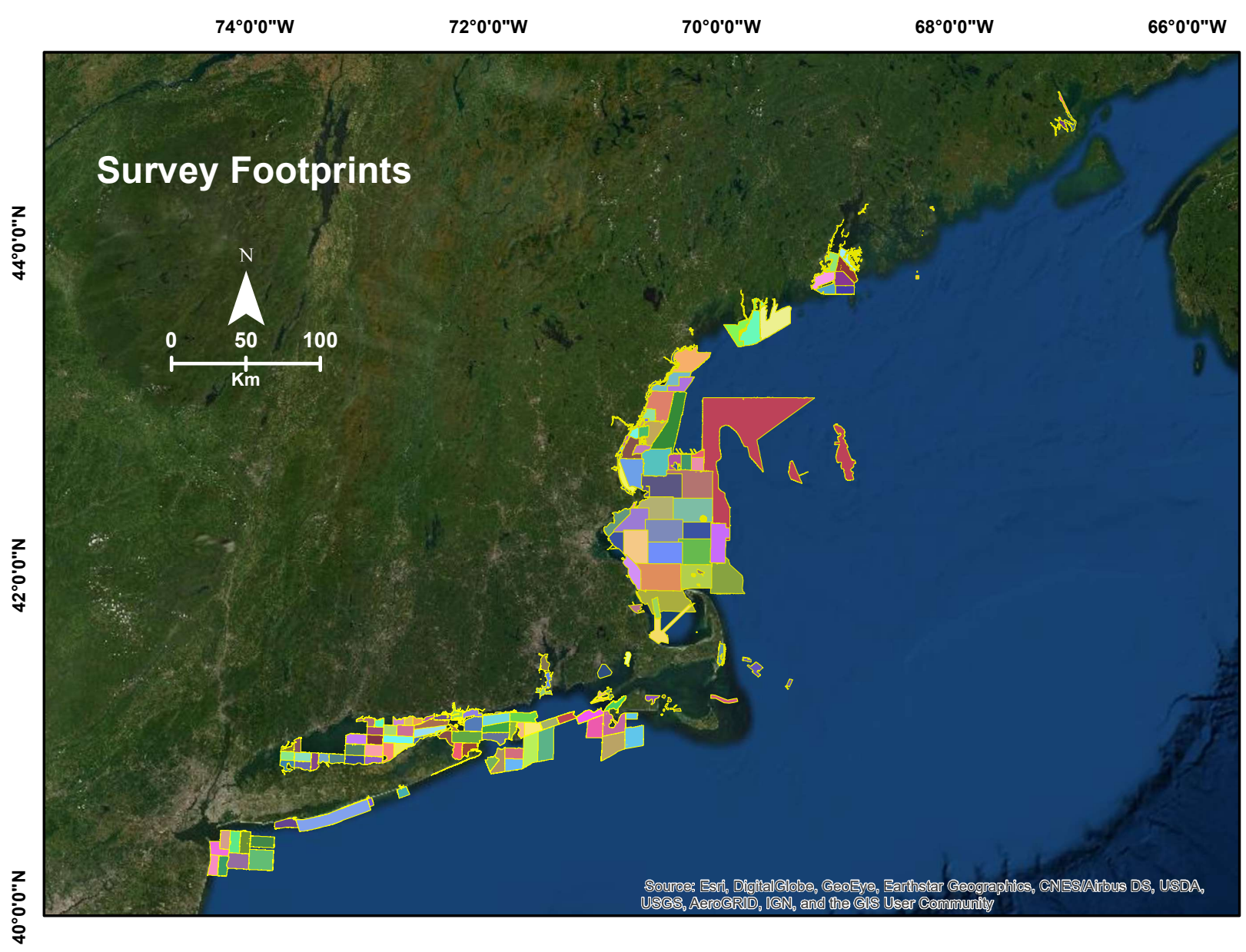

Figure 1. Multibeam echosounder surveys included in the "Northeast Bathymetry and Backscatter Compilation: Western Gulf of Maine, Southern New England, and Long Island".

\section{Bathymetry}

One hundred ninety-six surveys conducted by multiple agencies were used to construct the bathymetry compilations. The major agencies and groups include: National Oceanic and Atmospheric Administration (NOAA) National Ocean Survey (NOS); United States Geological Survey (USGS); University of New Hampshire (UNH) Center for Coastal and Ocean Mapping and Joint Hydrographic Center (CCOM/JHC); Gulf of Maine Marine Institute (GOMMI); United States Army Corps of Engineers (USACE); Maine Coastal Mapping Initiative (MCMI); and private organizations (e.g., Science Applications International Corporation, Inc., SAIC). The surveys are listed in Appendices A and B.

\section{High-Resolution Bathymetry Synthesis}

The high-resolution bathymetry synthesis covers two regions: the Western Gulf of Maine (Figure 2) and Southern New England and Long Island (Figure 3). The Western Gulf of Maine (WGOM) map extends from southern Maine to Massachusetts Bay. The high-resolution bathymetry synthesis was not extended further north into Maine due to the lack of accessible MBES surveys. However, relatively good coverage was obtained from southern Maine to Cape Cod and seaward to Jeffreys Ledge. The Southern New 
England and Long Island bathymetry synthesis extends from Cape Cod south to New York Harbor and includes the inner shelf off Long Island and Long Island Sound. The MBES coverage in Long Island Sound is relatively complete. However, the high-resolution MBES bathymetry coverage along the Atlantic Coast from south of Cape Cod to New York is sparse, leaving wide gaps in coverage. All MBES surveys that were available and known to the authors are included in the Compilation.

The high-resolution bathymetry syntheses are primarily composed of MBES surveys enhanced by lidar in very shallow water. The original surveys used in the Compilation were collected over a long time period and gridded over a large range. The survey dates range from 1988 to 2019, but the majority ( 82\%) have been carried out since 2005 . Although the cell size for the surveys ranges from $0.5 \mathrm{~m}$ to $16 \mathrm{~m}$, the highest resolution gridding was used for the Compilation. In almost all cases, the larger grid sizes were only used for very small areas.

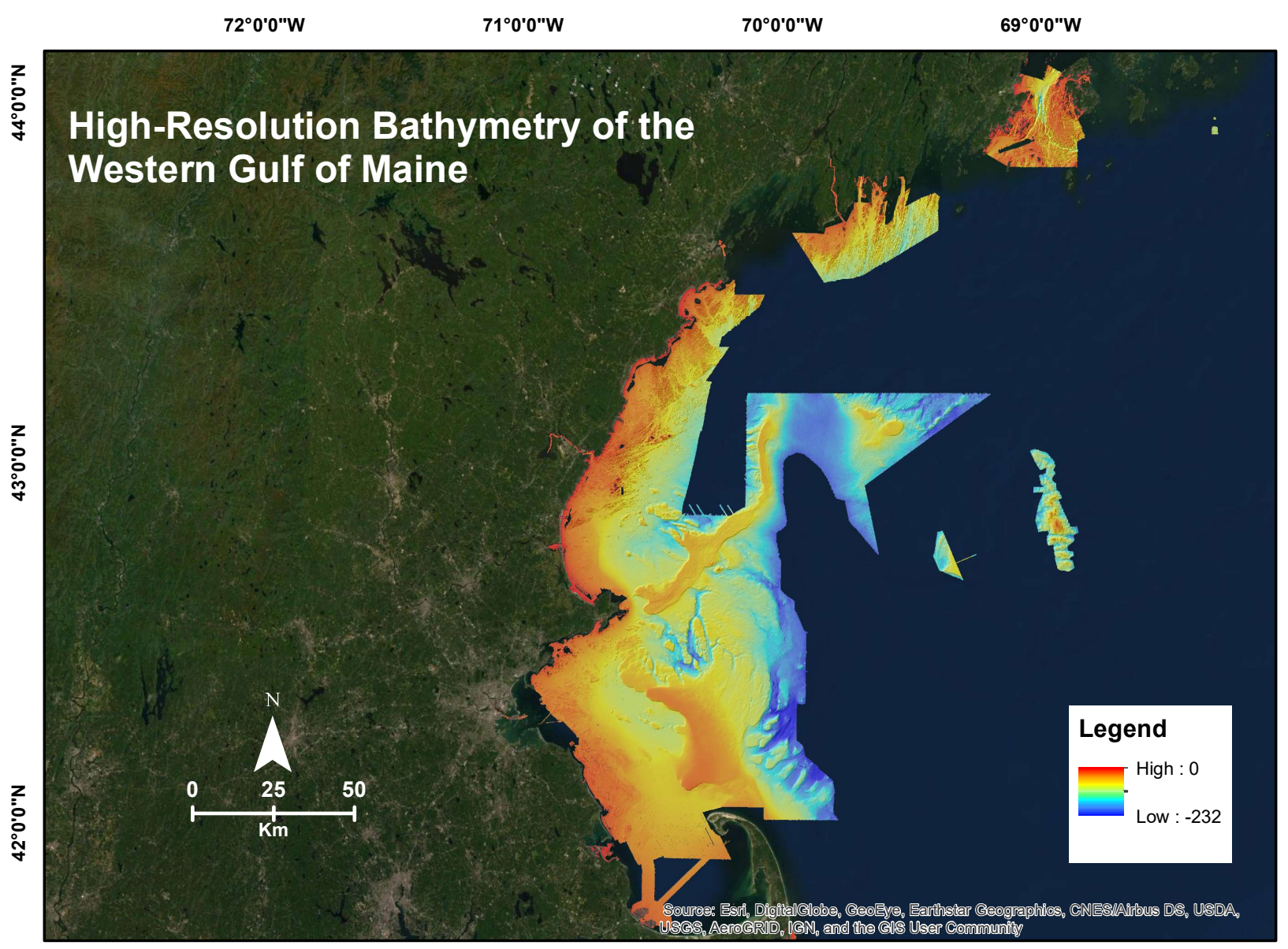

Figure 2. High-resolution bathymetry of the Western Gulf of Maine gridded at $4 m$. The vertical exaggeration is five. 


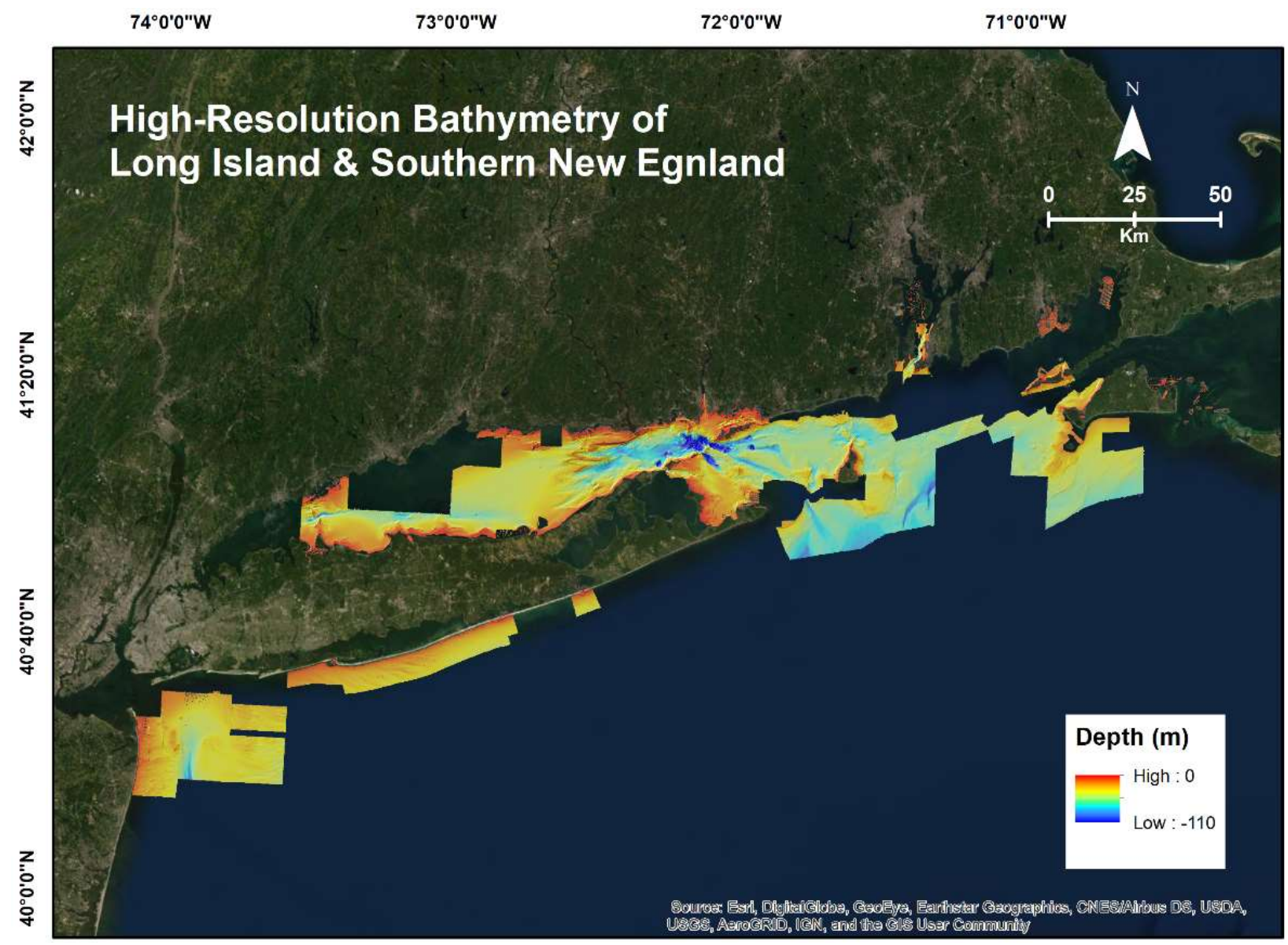

Figure 3. High-resolution bathymetry of Southern New England and Long Island Sound gridded at $4 m$. The vertical exaggeration is five.

Each survey was brought into Global Mapper 20, re-projected to WGS 1984 UTM Zone 19N, Transverse Mercator, and resampled at a $4 \mathrm{~m}, 8 \mathrm{~m}$, and $16 \mathrm{~m}$ cell sizes using bilinear interpolation. Each survey was ranked based on resolution and date and overlaid in global mapper from the highest resolution to the lowest resolution to develop the composite surface. A new shoreline for the entire area was made to ensure a clean landward boundary. To produce more uniform composites, the mosaic was resampled at $4 \mathrm{~m}, 8 \mathrm{~m}$, and $16 \mathrm{~m}$ and exported as 32-bit GeoTiffs. Final maps mere produced in ArcGIS. The original gridding, survey source, and other relevant information are included in the metadata for each survey presented in Appendices A and B. 


\section{Regional Bathymetry Map}

The regional bathymetry compilation extends from northern Maine to New York City and over much of the Gulf of Maine, southern New England, and Long Island Sound. The regional bathymetry map was built using the same bathymetry and procedure described previously but also includes older surveys of a much lower resolution or existing regional syntheses. This included the Global Multi-Resolution Topography (GMRT) synthesis that is maintained as a multi-resolution gridded global Digital Elevation Model (DEM) and includes cleaned, processed ship-based multibeam sonar data at their full spatial resolution ( $100 \mathrm{~m}$ in the deep sea) (https://www.gmrt.org/about/). Global Multi-Resolution Topography (GMRT) grids were combined with high-resolution multibeam data available from CCOM and NOS and gridded at 16m (Figure 4).

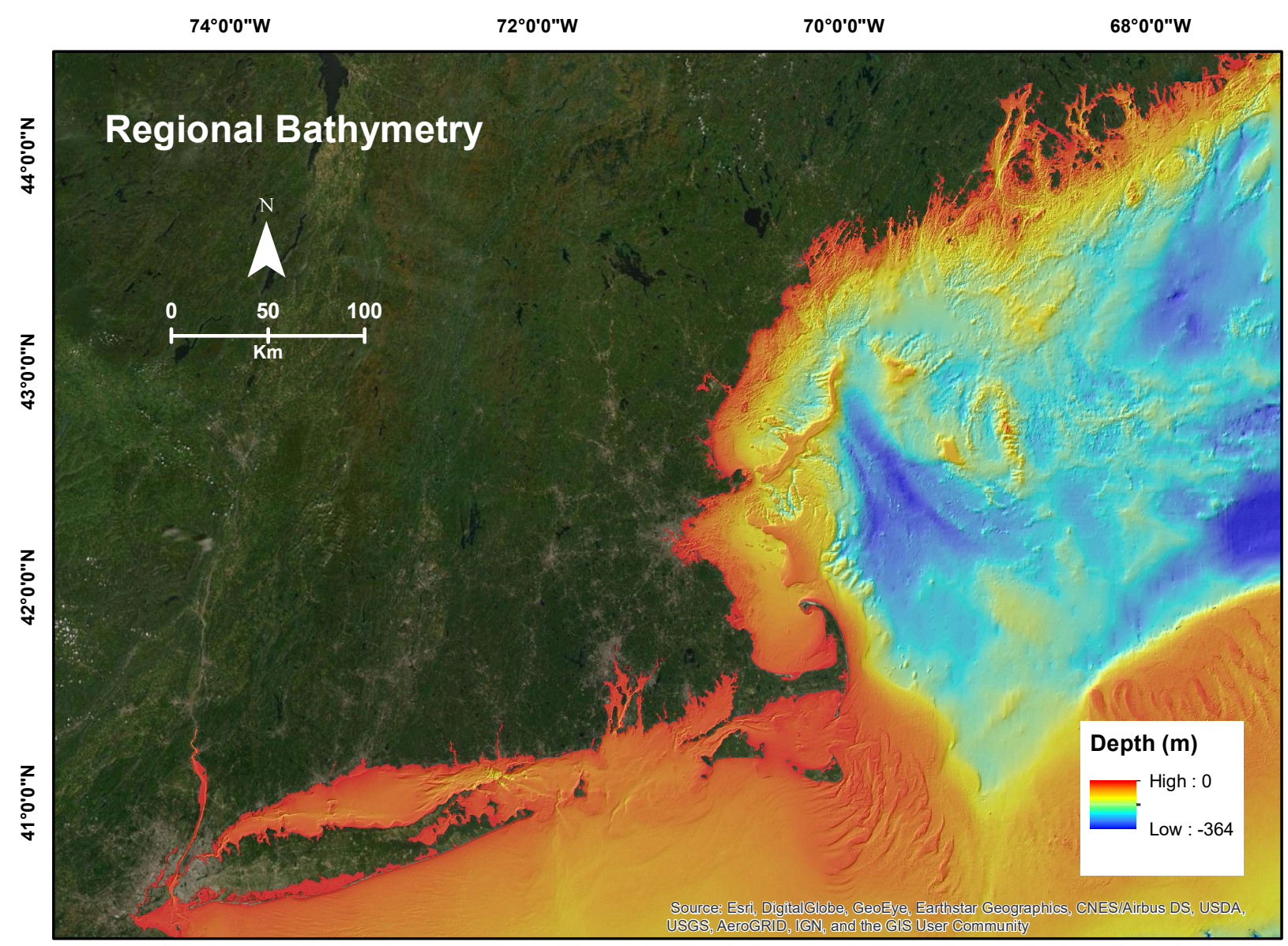

Figure 4. Regional bathymetry for the U.S. Northeast gridded at $16 \mathrm{~m}$. The vertical exaggeration is five. 


\section{UNH CCOM/JHC High-Resolution Bathymetry and Backscatter Surveys}

The UNH CCOM/JHC Hydrographic Field Course MBES surveys, which were primarily conducted on the continental shelf off $\mathrm{NH}$, feature very high-resolution MBES bathymetry with co-registered backscatter. Backscatter, or reflectivity, is the strength of the acoustic signal that returns to the transponder and is strongly affected by complex interactions with seafloor properties such as bottom sediment texture, roughness, and biota. Although MBES backscatter can be problematic due to calibration issues and differences in instrumentation used in surveys (e.g., frequency), it often provides valuable information concerning the seafloor. The bathymetry from the Hydrographic Field Course is gridded between 0.5 and $2.0 \mathrm{~m}$, and the backscatter is gridded at the same or finer resolution. The reflectivity mosaics primarily use decibel units which allow quantitative analysis. The Field Course surveys are presented separately in the Compilation and include the bathymetry and the backscatter (Figure 5).

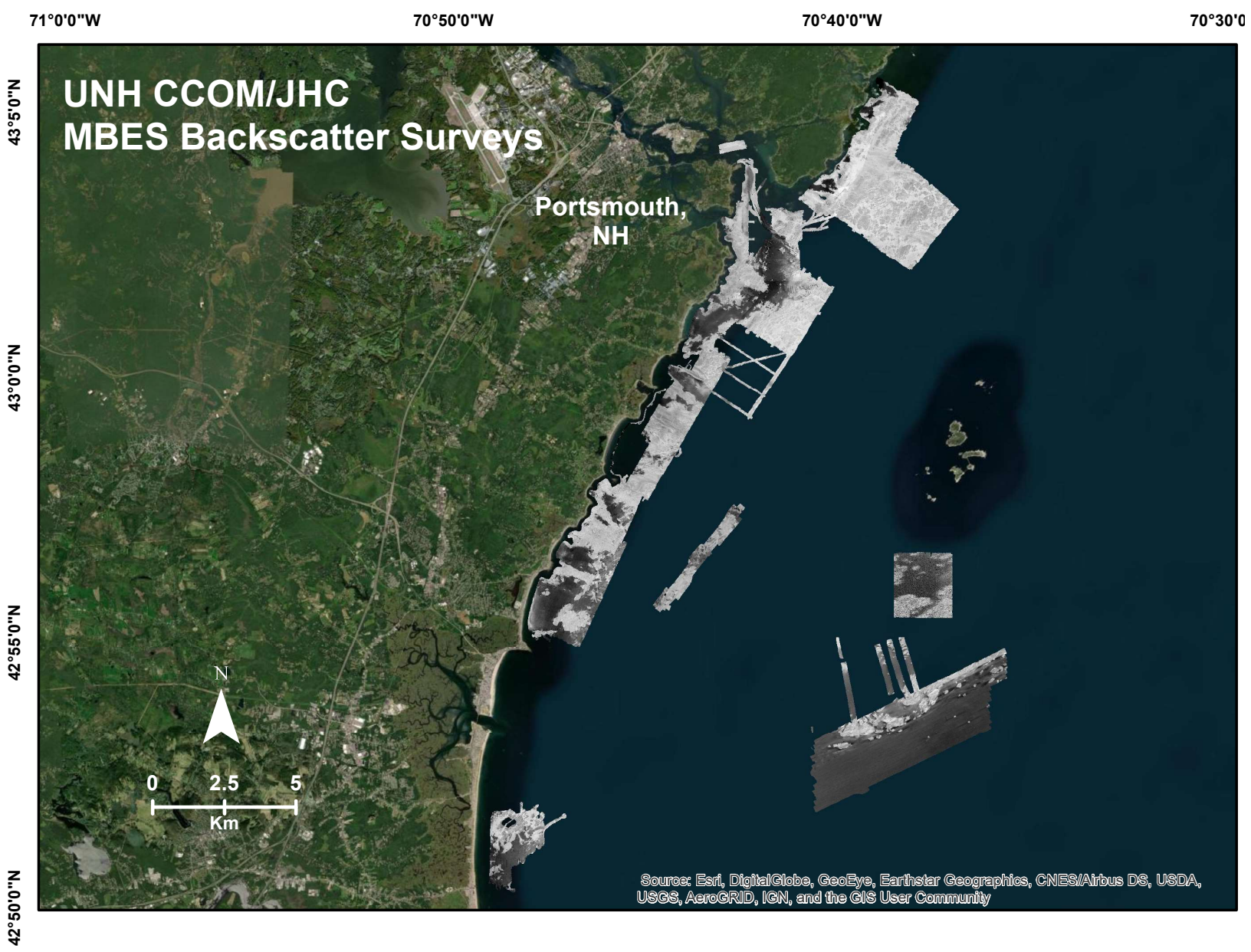

Figure 5. UNH CCOM/JHC Hydrographic Field Course MBES surveys from the NH continental shelf. 


\section{Multibeam Echosounder Backscatter Syntheses}

Two grayscale backscatter mosaics incorporating multiple backscatter surveys are included in the Compilation that cover the inner shelf off New Hampshire and Massachusetts Bay and are referred to here as the USGS Backscatter Composite and the CCOM/JHC Backscatter Synthesis.

The USGS Composite includes MBES and side scan sonar surveys gridded at $10 \mathrm{~m}$ and covers the continental shelf from the NH border to Massachusetts Bay, including parts of Jeffreys Ledge and Stellwagen Bank (Figure 6). Details and metadata for the USGS synthesis are given in Pendleton et al. (2013).

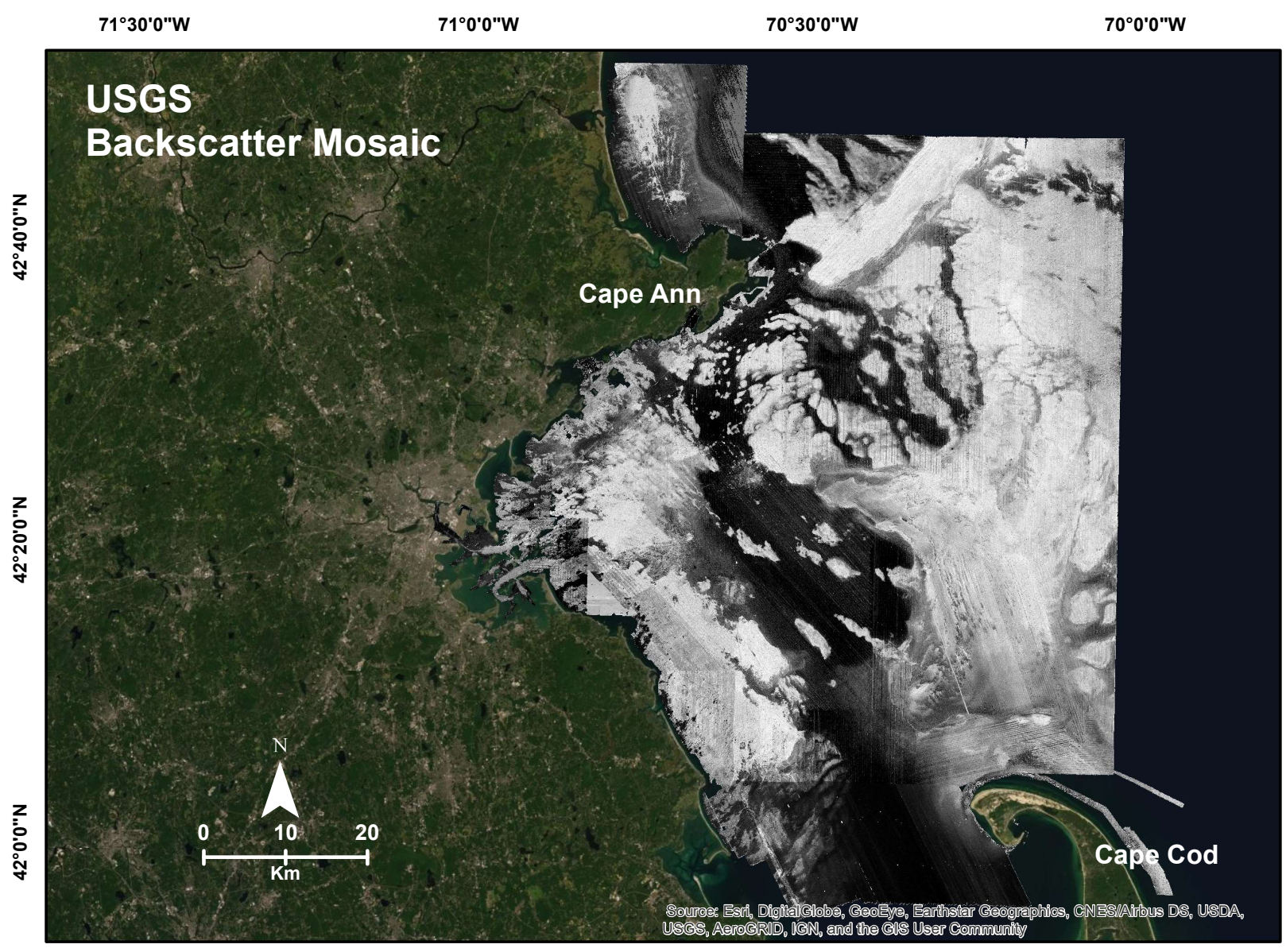

Figure 6. Backscatter mosaic developed by the USGS (see Pendleton et al., 2013). 


\section{UNH CCOM/JHC WGOM Backscatter Synthesis}

In order to develop a composite of MBES backscatter for the NH shelf, a subset of available surveys was assembled that were available from NOS and CCOM/JHC. No attempt was made to include all MBES surveys in the region due to the difficulties of combining varying datasets. Instead, a subset (twelve) for a region off New Hampshire was chosen. The UNH CCOM/JHC surveys were processed by survey in QPS Fledermaus Geocoder Toolbox (FMGT). However, some of the NOS backscatter mosaics used in this compilation contained residual artifacts that required pre-processing. The NOS surveys were then processed in CARIS and FMGT. The additional processing of the NOS MBES is described in detail in Ward et al. (2016). Using ERSI ArcGIS, the backscatter surveys were then standardized and rescaled using a $Z$ score normalization method and mosaicked. Ultimately, a mosaic gridded at $2.0 \mathrm{~m}$ was built that minimized the artifacts and allowed visual interpretation. However, the result is a qualitative product showing high and low reflectivity that is somewhat inconsistent across surveys with different frequencies. As a result, quantitative analysis using the backscatter mosaic is not possible. However, the UNH $\mathrm{CCOM} / \mathrm{JHC}$ surveys can be used for quantitative analysis (Figure 7).

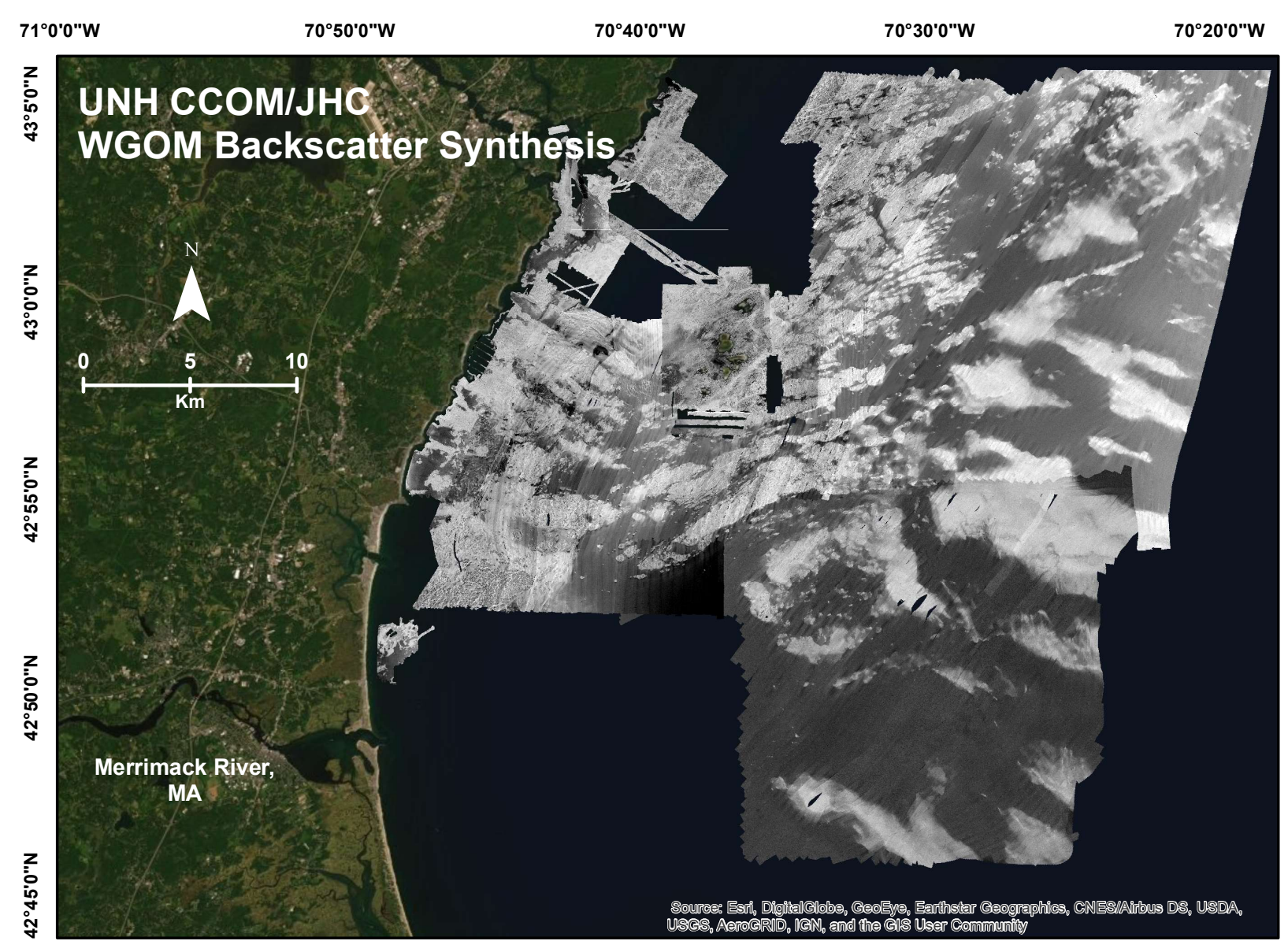

Figure 7. UNH CCOM/JHC Backscatter Synthesis (WGOM Backscatter Synthesis) gridded at 2.0m. 


\section{Web Serving}

The "Northeast Bathymetry and Backscatter Compilation: Western Gulf of Maine, Southern New England, and Long Island Sound" is available via the UNH CCOM/JHC web site at:

(https://maps.ccom.unh.edu/portal/apps/webappviewer/index.html?id=5d314116ad094afebbd02ffc18 5164f6); accessed May 2021. The Compilation is web-served using ArcGIS Server/ArcGIS Portal and rendered with web-served dynamic interactive maps written in JavaScript. The interactive maps can display the multibeam synthesis, the backscatter synthesis, and the individual surveys for the UNH CCOM/JHC Hydrographic Field Course, and also query information on each of the surveys or grids (e.g., original gridding, survey source, and other relevant information).

\section{Summary}

A very large and diverse set of high-resolution MBES surveys were successfully brought together and combined into maps that display the bathymetry gridded at $4 \mathrm{~m}, 8 \mathrm{~m}$, and $16 \mathrm{~m}$ in the "Northeast Bathymetry and Backscatter Compilation: Western Gulf of Maine, Southern New England, and Long Island Sound" (Figures 1, 2 and 3). In addition, a regional bathymetry surface gridded at $16 \mathrm{~m}$ is included which utilizes lower resolution bathymetry and existing regional syntheses (Figure 4). Available backscatter from selected MBES surveys and existing syntheses are also presented which cover the inner shelf from southern Maine to Cape Cod (Figures 5, 6 and 7). Collectively, these products summarize the highresolution bathymetric coverage of the U.S. Northeast inner continental shelf. The Compilation will aid visualization and analyses of seafloor surficial geology, habitats, and marine minerals. Examples of the quality and resolution of the bathymetry and backscatter are shown by the enlargements of the bathymetry survey re-gridded at $4 \mathrm{~m}$ (Figures $8,9,10$, and 11 ).

\section{References}

Pendleton, E.A., Baldwin, W.E., Barnhardt, W.A., Ackerman, S.D., Foster, D.S., Andrews, B.D., and Schwab, W.C., 2013, Shallow geology, seafloor texture, and physiographic zones of the Inner Continental Shelf from Nahant to northern Cape Cod Bay, Massachusetts: U.S. Geological Survey Open-File Report 2012-1157. http://pubs.usgs.gov/of/2012/1157/.

Ward, L.G., Johnson, P., Nagel, E., McAvoy, Z.S., and Vallee-Anziani, M., 2016, Western Gulf of Maine bathymetry and backscatter synthesis: BOEM/New Hampshire Cooperative Agreement (Contract M14ACO0010) Technical Report, BOEM Marine Minerals Branch, 381 Elden Street, Herndon, VA, 20170. 18 pp, https://dx.doi.org/10.34051/p/2021.27 
$70^{\circ} 46^{\prime} 0^{\prime \prime W}$

$70^{\circ} 44^{\prime} 0^{\prime \prime} \mathrm{W}$

$70^{\circ} 42^{\prime} 0^{\prime \prime} \mathrm{W}$

$70^{\circ} 40^{\circ} 0^{\prime \prime W}$

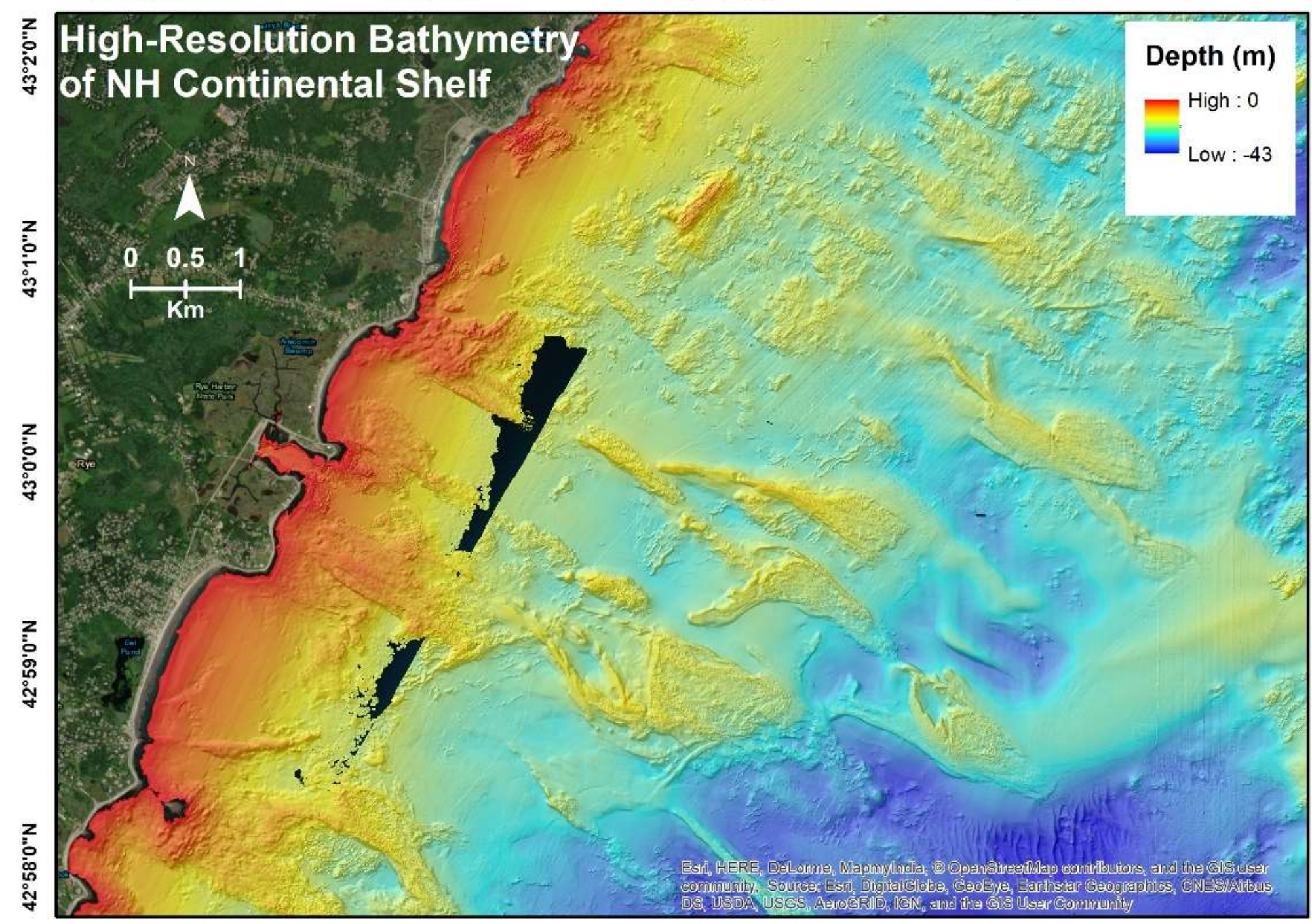

Figure 8. High-resolution bathymetry off the NH inner shelf. Many of the northwest-southeast trending features are marine-modified glacial features that extend onto shore. The vertical exaggeration is five. 


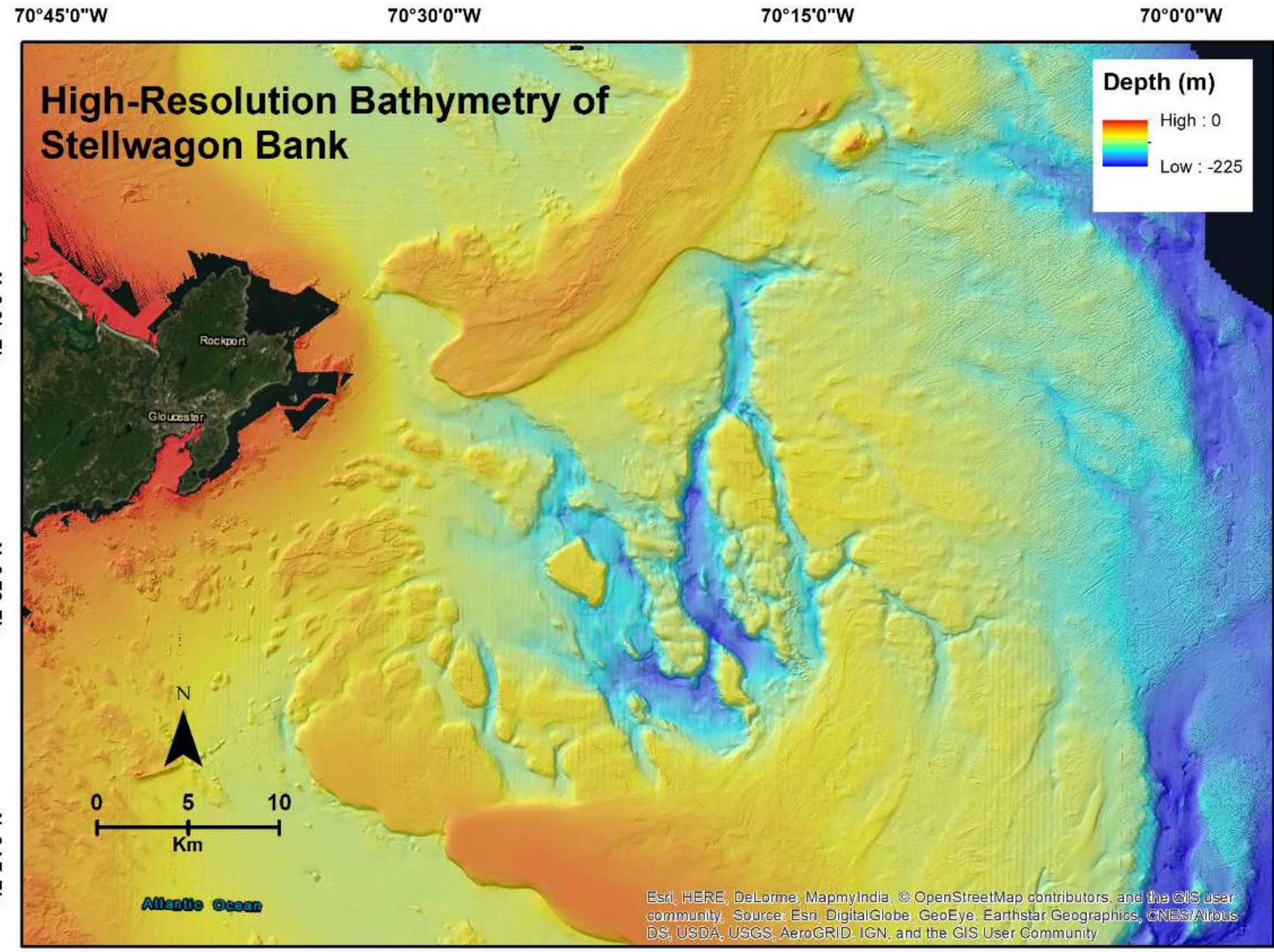

Figure 9. High-resolution bathymetry off Cape Ann, MA showing the complexity of the seafloor at the southern end of Jeffreys Ledge (top) and Stellwagen Bank (lower middle). The vertical exaggeration is ten. 


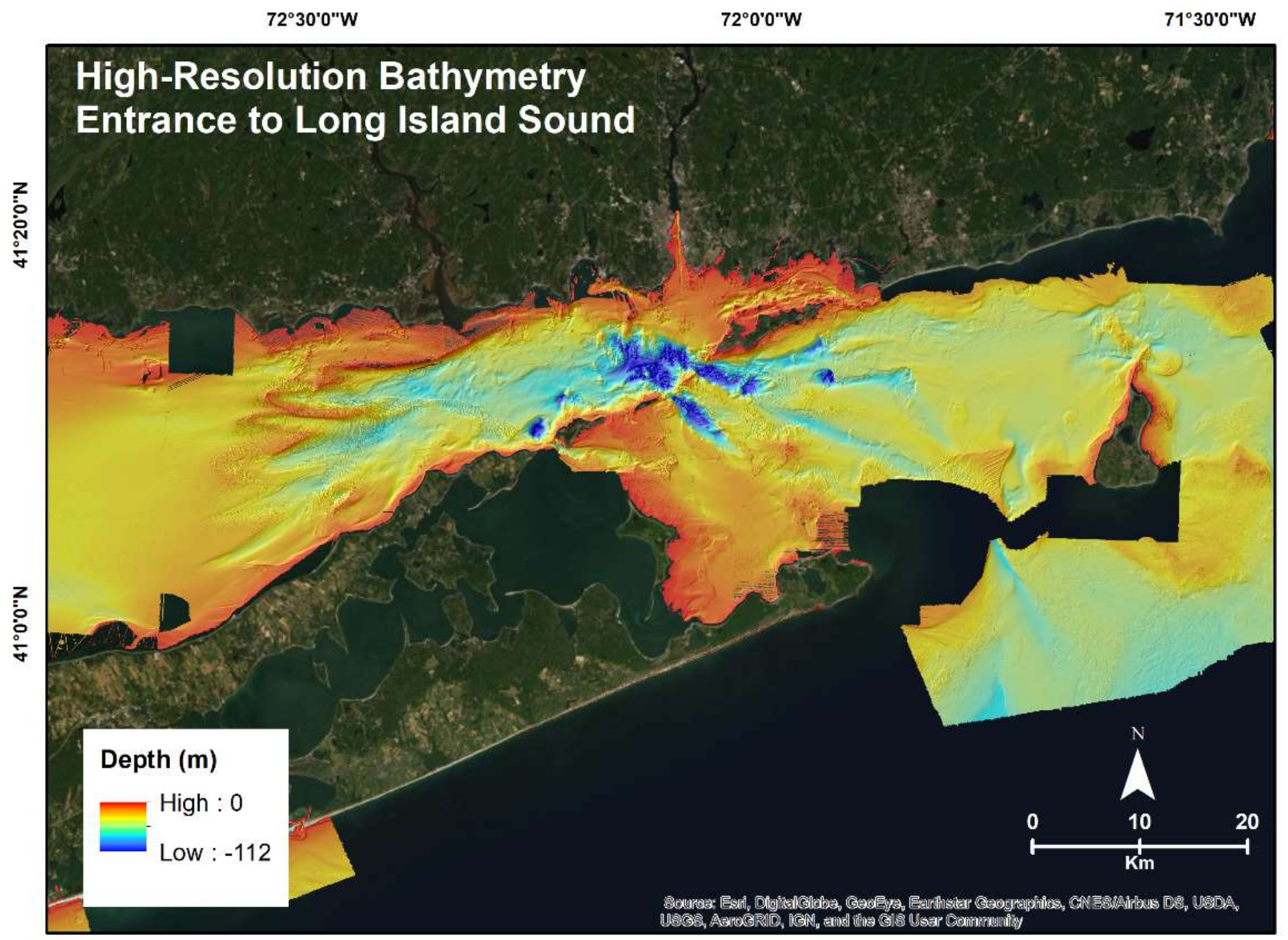

Figure 10. High-resolution bathymetry of the entrance to Long Island Sound. Figure 11 is an enlargement of the narrows at the entrance. The vertical exaggeration is five. 


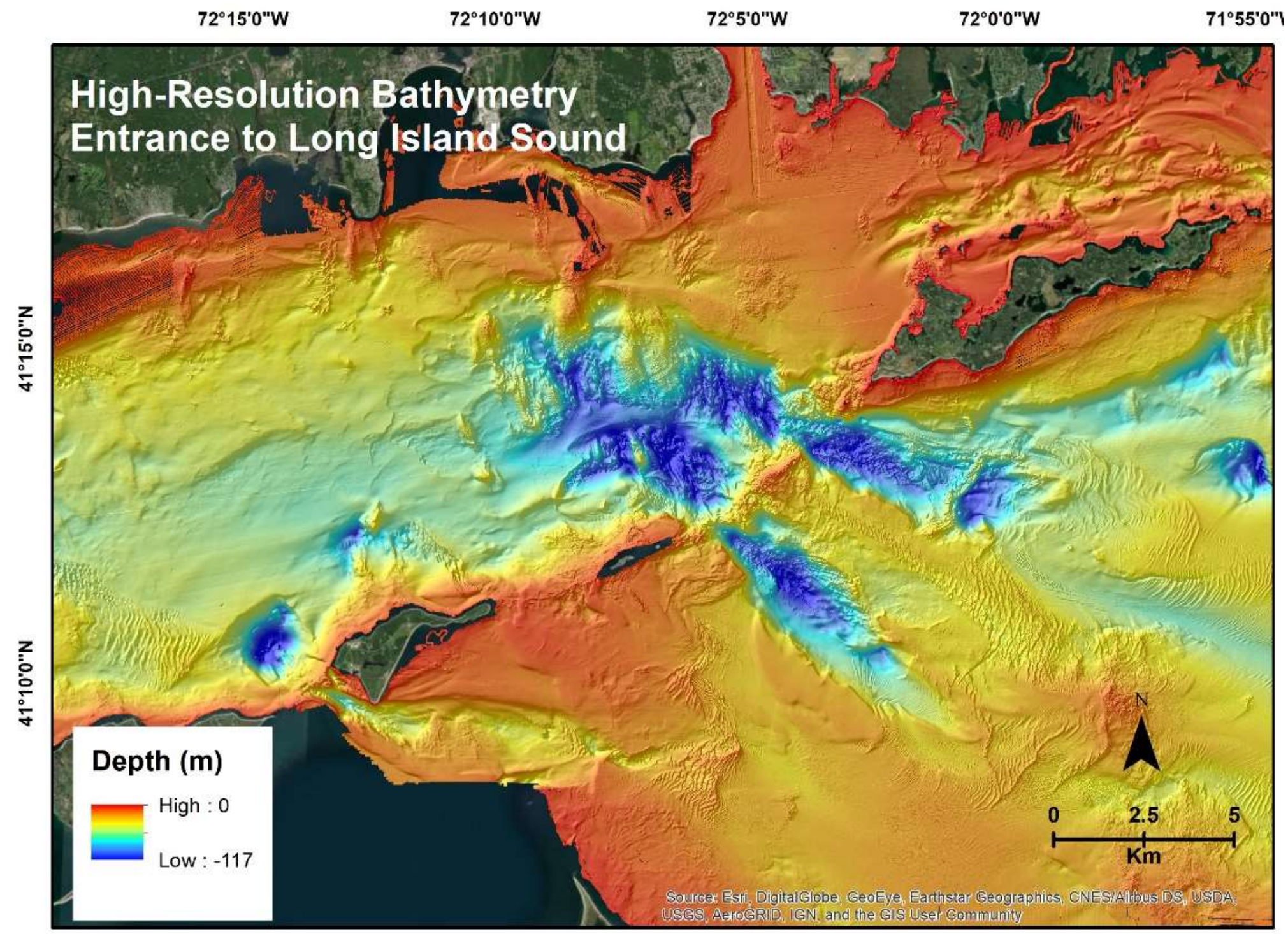

Figure 11. High-resolution bathymetry of the entrance to Long Island Sound showing an enlargement of the narrows. The vertical exaggeration is ten. 
Appendix A: Metadata for bathymetry and backscatter surveys used for the Western Gulf of Maine

\begin{tabular}{|c|c|c|c|c|c|c|c|}
\hline Agency & Survey & Year & Data Type & Cell Size (m) & System & Frequency & Data Location \\
\hline NOAA & D00149 & 2009 & MB & 1 & Reson Seabat 7125 & $400 \mathrm{kHz}$ & NCEI \\
\hline NOAA & D00185 & 2013 & MB & $4,8,16$ & Reson 7111 and 7125 & $75 \mathrm{kHz}$ & NCEI \\
\hline NOAA & F00524 & 2005 & $\mathrm{MB}$ & 0.75 & Simrad EM3002 & $445 \mathrm{kHz}$ & NCEI \\
\hline NOAA & F00545 & 2007 & $\mathrm{MB}$ & 0.75 & Simrad EM3000 & $445 \mathrm{kHz}$ & NCEI \\
\hline NOAA & F00553 & 2008 & $\mathrm{MB}$ & $0.50,2$ & Simrad EM3002 & $445 \mathrm{kHz}$ & NCEI \\
\hline NOAA & F00574 & 2009 & MB & 1,2 & Reson Seabat 7125 and 8125 & & NCEI \\
\hline NOAA & F00603 & 2011 & MB & $0.5,2$ & Reson Seabat 7125 & $401 \mathrm{kHz}$ & NCEI \\
\hline NOAA & F00619 & 2012 & MB & 0.5 & Kongsberg EM3002 & $300 \mathrm{kHz}$ & NCEI \\
\hline NOAA & H10763 & 1997 & MB & 2 & Reson 9003 & $445 \mathrm{kHz}$ & NCEI \\
\hline NOAA & H10771 & 1997 & MB & 2 & Reson 9003 & $455 \mathrm{kHz}$ & NCEI \\
\hline NOAA & H11014 & 2000 & MB & 1 & Reson 8101 & $240 \mathrm{kHz}$ & NCEI \\
\hline NOAA & H11277 & 2003 & MB & $0.5,1$ & Reson 8101 \& 8125 & $239 \mathrm{kHz}$ and $455 \mathrm{kHz}$ & NCEI \\
\hline NOAA (Fugro Pelagos) & H11296 & 2005 & $\mathrm{MB}$ & 5 & SHOALS 1000T & & NCEI \\
\hline NOAA & $\mathrm{H} 11421$ & 2005 & $\mathrm{MB}$ & $4,6,8$ & Kongsberg EM1002 & $95 \mathrm{kHz}$ & NCEI \\
\hline NOAA & $\mathrm{H} 11467$ & 2005 & MB & 1 & Kongsberg EM3000 & $300 \mathrm{kHz}$ & NCEI \\
\hline NOAA & H11636 & 2007 & MB & 2 & Kongsberg EM3002 & $300 \mathrm{kHz}$ & NCEI \\
\hline NOAA & H11695 & 2007 & $\mathrm{MB}$ & 1,2 & Reson $7125,8101 \& 8125$ & $200 / 400 \mathrm{kHz}, 240 / 455 \mathrm{kHz}$ & NCEI \\
\hline NOAA & $\mathrm{H} 12256$ & 2005 & $\mathrm{MB}$ & $0.5,1,2,4,8$ & Kongsberg EM3002 & $300 \mathrm{kHz}$ & NCEI \\
\hline NOAA & $\mathrm{H} 12477$ & 2012 & $\mathrm{MB}$ & $1,2,4,8$ & Teledyne RESON SeaBat 7125 SV2 & & NCEI \\
\hline NOAA & $\mathrm{H} 12478$ & 2012 & $\mathrm{MB}$ & $1,2,4$ & Reson 7125 SV2 & & NCEI \\
\hline NOAA & $\mathrm{H} 12613$ & 2013 & $\mathrm{MB}$ & 2,4 & Reson 7125 & $400 \mathrm{kHz}$ & NCEI \\
\hline NOAA & H12614 & 2013 & MB & $0.5,2,4$ & Reson 7125 & $400 \mathrm{kHz}$ & NCEI \\
\hline NOAA & $\mathrm{H} 12615$ & 2013 & $\mathrm{MB}$ & $0.5,2,4$ & Reson 7125 & $400 \mathrm{kHz}$ & NCEI \\
\hline NOAA & H12696 & 2014 & MB & $0.5,2,4$ & Reson 7125 & $400 \mathrm{kHz}$ & NCEI \\
\hline NOAA & H12697 & 2014 & MB & $0.5,2,4,8$ & Reson 7125 & $400 \mathrm{kHz}$ & NCEI \\
\hline NOAA & H12698 & 2014 & MB & $2,4,8$ & Reson 7125 & $400 \mathrm{kHz}$ & NCEI \\
\hline NOAA & H12725 & 2015 & MB & Variable Resolution & Reson 7125 & $400 \mathrm{kHz}$ & NCEI \\
\hline NOAA & $\mathrm{H} 12726$ & 2015 & $\mathrm{MB}$ & $1,2,4$ & Reson 7125 & $400 \mathrm{kHz}$ & NCEI \\
\hline NOAA & W00037 & 2003 & $\mathrm{MB}$ & 5,10 & Simrad EM1002 & $95 \mathrm{kHz}$ & NCEI \\
\hline NOAA & W00038 & 2003 & $\mathrm{MB}$ & 5 & Simrad EM1002 & $95 \mathrm{kHz}$ & NCEI \\
\hline NOAA & W00039 & 2003 & $\mathrm{MB}$ & 5,10 & Simrad EM1002 & $95 \mathrm{kHz}$ & NCEI \\
\hline NOAA & W00040 & 2003 & $\mathrm{MB}$ & 5,10 & Simrad EM1002 & $95 \mathrm{kHz}$ & NCEI \\
\hline
\end{tabular}


Appendix A: continued

\begin{tabular}{|c|c|c|c|c|c|c|c|}
\hline Agency & Survey & Year & Data Type & Cell Size (m) & System & Frequency & Data Location \\
\hline NOAA & W00041 & 2003 & MB & 5,10 & Simrad EM1002 & $95 \mathrm{kHz}$ & NCEI \\
\hline NOAA & W00044 & 2003 & $\mathrm{MB}$ & 5 & Simrad EM1002 & $95 \mathrm{kHz}$ & NCEI \\
\hline NOAA & W00045 & 2003 & $\mathrm{MB}$ & 5 & Simrad EM1002 & $95 \mathrm{kHz}$ & NCEI \\
\hline NOAA & W00046 & 2003 & $\mathrm{MB}$ & 10 & Simrad EM1002 & $95 \mathrm{kHz}$ & NCEI \\
\hline NOAA & W00047 & 2003 & $\mathrm{MB}$ & 10 & Simrad EM1002 & $95 \mathrm{kHz}$ & NCEI \\
\hline NOAA & W00048 & 2003 & $\mathrm{MB}$ & 8,10 & Simrad EM1002 & $95 \mathrm{kHz}$ & NCEI \\
\hline NOAA & W00050 & 2003 & $\mathrm{MB}$ & 2,4 & Simrad EM1002 & $95 \mathrm{kHz}$ & NCEI \\
\hline NOAA & W00051 & 2003 & $\mathrm{MB}$ & 2,4 & Simrad EM1002 & $95 \mathrm{kHz}$ & NCEI \\
\hline NOAA & W00052 & 2003 & MB & 2,4 & Simrad EM1002 & $95 \mathrm{kHz}$ & NCEI \\
\hline NOAA & W00053 & 2003 & $\mathrm{MB}$ & 2,4 & Simrad EM1002 & $95 \mathrm{kHz}$ & NCEI \\
\hline USGS (UNH and SAIC) & W00181 & 2007 & $\mathrm{MB}$ & 2,4 & Reson 8101 & $240 \mathrm{kHz}$ & NCEI \\
\hline GOMMI (UNH and SAIC) & W00194 & 2005 & $\mathrm{MB}$ & 8 & RESON 8101 & $240 \mathrm{kHz}$ & NCEI \\
\hline GOMMI( UNH and SAIC) & W00195 & 2005 & MB & Variable Resolution & Reson SeaBat 8101 & $240 \mathrm{kHz}$ & NCEI \\
\hline Maine Coastal Mapping Initiative & W00288 & 2014 & MB & $2,4,8$ & Kongsberg Maritime EM 2040C & $300 \mathrm{kHz}$ & NCEI \\
\hline NOAA (USACE JALBTCX) & W00313 & 2015 & Lidar & 5 & CZMIL system & & NCEI \\
\hline UNH (JHC/CCOM) & & 2002 & $\mathrm{MB}$ & 1 & & & UNH \\
\hline UNH (JHC/CCOM) & & 2003 & MB & 1 & Reson $8101 \& 8125$ & $240 \mathrm{kHz} \& 455 \mathrm{kHz}$ & UNH \\
\hline UNH (JHC/CCOM) & & 2004 & MB & 1 & & & UNH \\
\hline UNH (JHC/CCOM) & W00178 & 2006 & MB & $0.5,1$ & Kongsberg EM3002 Dual Head & $293 / 307 \mathrm{kHz}$ & NCEI \\
\hline UNH (JHC/CCOM) & W00276 & 2007 & MB & 1 & Kongsberg EM3002 Dual Head & $293 / 307 \mathrm{kHz}$ & NCEI \\
\hline UNH (JHC/CCOM) & W00277 & 2007 & MB & 1 & Kongsberg EM3002 Dual Head & $293 / 307 \mathrm{kHz}$ & NCEI \\
\hline UNH (JHC/CCOM) & W00273 & 2008 & MB & $0.5,1$ & Kongsberg EM3002 Dual Head & $293 / 307 \mathrm{kHz}$ & NCEI \\
\hline UNH (JHC/CCOM) & W00274 & 2010 & MB & 1,2 & Kongsberg EM3002 Dual Head & $293 / 307 \mathrm{kHz}$ & NCEI \\
\hline UNH (JHC/CCOM) & & 2011 & MB & 2 & Reson 7125 & $200 / 400 \mathrm{kHz}$ & UNH \\
\hline UNH (JHC/CCOM) & & 2008 & MB & 1 & & & UNH \\
\hline NOAA & F00508 & 2005 & MB & $2,2.5$ & Simrad EM1002 & $95 \mathrm{kHz}$ & NCEI \\
\hline NOAA & F00620 & 2012 & MB & 0.5 & Kongsberg EM3002 & $300 \mathrm{kHz}$ & NCEI \\
\hline NOAA & F00725 & 2018 & MB & Variable Resolution & Kongsberg Maritime EM 2040C & $300 \mathrm{kHz}$ & NCEI \\
\hline UNH (JHC/CCOM) & W00505 & 2017 & MB & 0.5 & KongsbergMaritime EM 2040 & $300 \mathrm{kHz}$ & NCEI \\
\hline NOAA & $\mathrm{H} 12257$ & 2010 & MB & 1,2 & Simrad EM3002 & $445 \mathrm{kHz}$ & NCEI \\
\hline NOAA & $\mathrm{H} 12258$ & 2010 & MB & 1,2 & Kongsberg EM3002 & $301 \mathrm{kHz}$ & NCEI \\
\hline NOAA & H12259 & 2010 & MB & $2,4,8$ & Kongsberg EM3002 & $302 \mathrm{kHz}$ & NCEI \\
\hline NOAA & $\mathrm{H} 12270$ & 2010 & MB & $1,2,4$ & Kongsberg EM3002 & $303 \mathrm{kHz}$ & NCEI \\
\hline NOAA (Fugro Pelagos) & H12884 & 2016 & MB and Lidar & $1,2,4,5,8,16$ & Reson 7125 and SHOALS-1000T & & NCEI \\
\hline NOAA & H12885 & 2016 & $\mathrm{MB}$ & $1,2,4,5,8$ & Reson 7125 & $400 \mathrm{kHz}$ & NCEI \\
\hline NOAA & H12886 & 2016 & $\mathrm{MB}$ & $1,2,4,5,8$ & Reson 7125 & $400 \mathrm{kHz}$ & NCEI \\
\hline NOAA & $\mathrm{H} 12887$ & 2016 & $\mathrm{MB}$ & $1,2,4,5,8$ & Reson 7125 & $400 \mathrm{kHz}$ & NCEI \\
\hline
\end{tabular}


Appendix A: continued

\begin{tabular}{|c|c|c|c|c|c|c|c|}
\hline Agency & Survey & Year & Data Type & Cell Size (m) & System & Frequency & Data Location \\
\hline UNH (SAIC) & & 2003 & $\mathrm{MB}$ & 5 & Reson 8101 & $240 \mathrm{kHz}$ & UNH \\
\hline UNH (JHC/CCOM) & W00501 & 2013 & MB & 0.5 & Kongsberg Maritime EM 2040 & $300 \mathrm{kHz}$ & NCEI \\
\hline UNH (JHC/CCOM) & W00503 & 2015 & $\mathrm{MB}$ & 1 & Kongsberg Maritime EM 2040 & $300 \mathrm{kHz}$ & NCEI \\
\hline UNH (JHC/CCOM) & W00504 & 2016 & $\mathrm{MB}$ & 0.5 & & & NCEI \\
\hline UNH (JHC/CCOM) & W00506 & 2018 & $\mathrm{MB}$ & 1 & R2Sonic 2024 & $300 \mathrm{kHz}$ & NCEI \\
\hline UNH (JHC/CCOM) & W00492 & 2019 & $\mathrm{MB}$ & Variable Resolution & R2Sonic 2026 & $450 \mathrm{kHz}$ & NCEI \\
\hline UNH (JHC/CCOM) & W00500 & 2001 & $\mathrm{MB}$ & 1 & SeaBat 8101 & $240 \mathrm{kHz}$ & NCEI \\
\hline USACE & & 2010 & Lidar & 2 & & & USACE \\
\hline USACE & & 2010 & Lidar & 4 & & & USACE \\
\hline USACE & & 2014 & Lidar & 2 & & & USACE \\
\hline USACE & & 2014 & Lidar & 2 & & & USACE \\
\hline USACE & & 2014 & Lidar & 2 & & & USACE \\
\hline USACE & & 2014 & Lidar & 2 & & & USACE \\
\hline USACE & & 2014 & Lidar & 2 & & & USACE \\
\hline USACE & & 2014 & Lidar & 2 & & & USACE \\
\hline USACE & & 2014 & Lidar & 2 & & & USACE \\
\hline USACE & & 2015 & Lidar & 1 & & & USACE \\
\hline USGS & & 1988 & $\mathrm{MB}$ & 10 & Simrad EM1000 & $95 \mathrm{kHz}$ & USGS \\
\hline NOAA & W00042 & 1995 & $\mathrm{MB}$ & 10 & Simrad EM1002 & $95 \mathrm{kHz}$ & NCEI \\
\hline NOAA (USACE JALBTCX) & W00203 & 2007 & Lidar & 5 & SHOALS $1000 T$ & & NCEI \\
\hline UNH (JHC/CCOM) & W00206 & 2009 & MB & 1 & Kongsberg EM3002 Dual Head & $293 / 307 \mathrm{kHz}$ & NCEI \\
\hline UNH (JHC/CCOM) & W00244 & 2012 & $\mathrm{MB}$ & $0.5,1$ & Simrad EM2040 & $300 \mathrm{kHz}$ & NCEI \\
\hline UNH (JHC/CCOM) & W00272 & 2005 & $\mathrm{MB}$ & 1,2 & Kongsberg Maritime EM 3002 & $300 \mathrm{kHz}$ & NCEI \\
\hline UNH (JHC/CCOM) & W00275 & 2007 & $\mathrm{MB}$ & 0.5 & Kongsberg Maritime EM 3002 & $300 \mathrm{kHz}$ & NCEI \\
\hline NOAA & W00289 & 2015 & $\mathrm{MB}$ & $1,2,4$ & Kongsberg Maritime EM 2040C & $300 \mathrm{kHz}$ & NCEI \\
\hline NOAA & W00384 & 2012 & $\mathrm{MB}$ & 2,4 & SeaBat 7125 SV & & NCEI \\
\hline NOAA & W00395 & 2008 & $\mathrm{MB}$ & $2,4,8$ & Kongsberg Maritime EM 1002 & $95 \mathrm{kHz}$ & NCEI \\
\hline NOAA & W00448 & 2016 & $\mathrm{MB}$ & $1,2,4,8$ & Kongsberg Maritime EM 2040C & $300 \mathrm{kHz}$ & NCEI \\
\hline NOAA & W00449 & 2016 & $\mathrm{MB}$ & 1 & Kongsberg Maritime EM $2040 \mathrm{C}$ & $300 \mathrm{kHz}$ & NCEI \\
\hline NOAA & W00450 & 2017 & $\mathrm{MB}$ & $1,2,4,8,16$ & Kongsberg Maritime EM 2040C & $300 \mathrm{kHz}$ & NCEI \\
\hline NOAA & W00451 & 2017 & $\mathrm{MB}$ & 1 & Kongsberg Maritime EM $2040 \mathrm{C}$ & $300 \mathrm{kHz}$ & NCEI \\
\hline USGS & W00483 & 2004 & MB & 5 & SEA Submatrix 2000 & & NCEI \\
\hline USGS & W00484 & 2005 & Bathymetric SSS & 5 & Sea SwathPlus-M Interferometric & $445 \mathrm{kHz}$ & NCEI \\
\hline USGS & W00486 & 2007 & Bathymetric SSS & 5 & Sea SwathPlus-M Interferometric & $445 \mathrm{kHz}$ & NCEI \\
\hline USGS & W00487 & 2007 & Bathymetric SSS & 5 & Sea SwathPlus-M Interferometric & $445 \mathrm{kHz}$ & NCEI \\
\hline UNH (JHC/CCOM) & & 2011 & MB & 2 & Reson 7125 & $200 / 400 \mathrm{kHz}$ & UNH \\
\hline UNH (JHC/CCOM) & W00504 & 2016 & MB & 0.5 & & & NCEI \\
\hline UNH (JHC/CCOM) & W00502 & 2014 & $\mathrm{MB}$ & 0.5 & Kongsberg Maritime EM 2040 & $400 \mathrm{kHz}$ & $\mathrm{NCEI}$ \\
\hline
\end{tabular}


Appendix B: Metadata for bathymetry and backscatter surveys used for Southern New England and Long Island

\begin{tabular}{|c|c|c|c|c|c|c|c|}
\hline Agency & Survey & Year & Data Type & Cell Size $(\mathrm{m})$ & System & Frequency & Data Location \\
\hline NOAA & F00561 & 2008 & $\mathrm{MB}$ & 2 & Simrad EM1002 & $445 \mathrm{kHz}$ & NCEI \\
\hline NOAA & F00660 & 2015 & MBVB & 2 & Reson SeaBat 7125 SV, Reson 7125 & $400 \mathrm{kHz}$ & NCEI \\
\hline NOAA & H11076 & 2004 & $\mathrm{MB}$ & $1,2,4$ & SeaBat 8125,8101 & $455 \mathrm{kHz}$ & NCEI \\
\hline NOAA (Tenix LADS Inc.) & H11224 & 2004 & Lidar & 4 & LADS MKII & & NCEI \\
\hline NOAA & H11251 & 2008 & $\mathrm{MB}$ & Variable Resolution & SeaBat $8125 \& 8101$ & $455 \mathrm{kHz}$ & NCEI \\
\hline NOAA & H11252 & 2004 & $M B$ & 1 & Simrad EM1002 RESON SeaBat 8125 & $455 \mathrm{kHz}$ & NCEI \\
\hline NOAA & H11346 & 2004 & $\mathrm{MB}$ & 3 & Simrad EM1002 RESON SeaBat 8125 & $455 \mathrm{kHz}$ & NCEI \\
\hline NOAA & H11360 & 2004 & MBVB & $0.5,1$ & Simrad EM1002 RESON SeaBat 8125 & $455 \mathrm{kHz}$ & NCEI \\
\hline NOAA & H11361 & 2004 & $\mathrm{MB}$ & $0.5,1,2$ & Simrad EM1002 RESON SeaBat 8125 & $455 \mathrm{kHz}$ & NCEI \\
\hline NOAA & $\mathrm{H} 11441$ & 2005 & MB & $0.4,0.8$ & SeaBat 8101,8125 & $455 \mathrm{kHz}$ & NCEI \\
\hline NOAA & H11445 & 2008 & MB & Variable Resolution & SeaBat 8125 \& 8101 & $455 \mathrm{kHz}$ & NCEI \\
\hline NOAA & H11446 & 2008 & $\mathrm{MB}$ & Variable Resolution & SeaBat $8125 \& 8101$ & $455 \mathrm{kHz}$ & NCEI \\
\hline NOAA & H11916 & 2008 & MB & 1,2 & SeaBat $8125 \& 8101$ & $455 \mathrm{kHz}$ & NCEI \\
\hline NOAA & H11920 & 2008 & $\mathrm{MB}$ & Variable Resolution & SeaBat 8125 \& 8101 & $455 \mathrm{kHz}$ & NCEI \\
\hline NOAA & H11921 & 2008 & $\mathrm{MB}$ & 1,2 & SeaBat $8125 \& 8101$ & $455 \mathrm{kHz}$ & NCEI \\
\hline NOAA & H11922 & 2008 & $\mathrm{MB}$ & 2 & SeaBat $8125 \& 7125$ & $455 \mathrm{kHz}$ & NCEI \\
\hline NOAA & H11995 & 2008 & $\mathrm{MB}$ & 2 & SeaBat $8125 \& 7125$ & $455 \mathrm{kHz}$ & NCEI \\
\hline NOAA & H11996 & 2008 & $\mathrm{MB}$ & 2 & SeaBat $8125 \& 7125$ & $455 \mathrm{kHz}$ & NCEI \\
\hline NOAA & H11997 & 2008 & MB & Variable Resolution & SeaBat 8125 \& 7125 & $455 \mathrm{kHz}$ & NCEI \\
\hline NOAA & H11999 & 2008 & $\mathrm{MB}$ & Variable Resolution & SeaBat $8125,7125 \& 8101$ & $455 \mathrm{kHz}$ & NCEI \\
\hline NOAA & H12009 & 2009 & $\mathrm{MB}$ & 2 & SeaBat $8125 \& 7125$ & & NCEI \\
\hline NOAA & H12010 & 2009 & $\mathrm{MB}$ & Variable Resolution & SeaBat 8125 \& 7125 & $455 \mathrm{kHz}$ & NCEI \\
\hline NOAA & H12011 & 2009 & $\mathrm{MB}$ & Variable Resolution & Seabat 7125 & & NCEI \\
\hline NOAA & H12013 & 2009 & MB & 2 & SeaBat 8125 \& 7125 & $455 \mathrm{kHz}$ & NCEI \\
\hline NOAA & H12015 & 2009 & $\mathrm{MB}$ & Variable Resolution & Seabat 7125 & & NCEI \\
\hline NOAA & H12033 & 2009 & $\mathrm{MB}$ & $0.5,2$ & SeaBat $8125 \& 7125$ & $455 \mathrm{kHz}$ & NCEI \\
\hline NOAA & H12036 & 2009 & $\mathrm{MB}$ & $0.5,1,2$ & Seabat 7125 & $445 \mathrm{kHz}$ & NCEI \\
\hline NOAA & H12137 & 2009 & $\mathrm{MB}$ & Variable Resolution & Seabat 7125 & & NCEI \\
\hline NOAA & H12139 & 2009 & $\mathrm{MB}$ & Variable Resolution & Seabat 7125 & & NCEI \\
\hline NOAA & H12158 & 2009 & $\mathrm{MB}$ & $0.5,2$ & Seabat 7125 & $445 \mathrm{kHz}$ & NCEI \\
\hline NOAA & H12296 & 2011 & $\mathrm{MB}$ & $0.5,1,2,4$ & Seabat 7125 & $445 \mathrm{kHz}$ & NCEI \\
\hline NOAA & H12298 & 2011 & $\mathrm{MB}$ & $0.5,1,2,4,8$ & Seabat 7125 & $445 \mathrm{kHz}$ & NCEI \\
\hline
\end{tabular}


Appendix B: continued

\begin{tabular}{|c|c|c|c|c|c|c|c|}
\hline Agency & Survey & Year & Data Type & Cell Size (m) & System & Frequency & Data Location \\
\hline NOAA & H12299 & 2011 & $\mathrm{MB}$ & Variable Resolution & Reson 7125 SV1 \& 7125 ROV & & NCEI \\
\hline NOAA & $\mathrm{H} 12324$ & 2011 & $\mathrm{MB}$ & $1,2,4$ & Simrad EM3002 & & NCEI \\
\hline NOAA & $\mathrm{H} 12386$ & 2011 & $\mathrm{MB}$ & Variable Resolution & Reson 7125 ROV & $400 \mathrm{kHz}$ & NCEI \\
\hline NOAA & $\mathrm{H} 12411$ & 2012 & $\mathrm{MB}$ & $0.5,2$ & Reson 7125 SV 1 \& 7125 ROV & $400 \mathrm{kHz}$ & NCEI \\
\hline NOAA & H12412 & 2012 & MB & Variable Resolution & Reson 7125 SV1 \& 7125 ROV & $400 \mathrm{kHz}$ & NCEI \\
\hline NOAA & $\mathrm{H} 12413$ & 2012 & $\mathrm{MB}$ & $1,2,4$ & Reson 7125 SV 1 \& 7125 ROV & $445 \mathrm{kHz}$ & NCEI \\
\hline NOAA & H12414 & 2012 & MB & 0.5 & Reson 7125 SV1 \& 7125 ROV & $445 \mathrm{kHz}$ & NCEI \\
\hline NOAA & $\mathrm{H} 12415$ & 2012 & $\mathrm{MB}$ & Variable Resolution & Reson 7125 & $400 \mathrm{kHz}$ & NCEI \\
\hline NOAA & $\mathrm{H} 12416$ & 2012 & $\mathrm{MB}$ & $0.5,2,4$ & SeaBat 7125 SV, Reson 7125 ROV & $400 \mathrm{kHz}$ & NCEI \\
\hline NOAA & H12417 & 2012 & MB & $0.5,2,4$ & SeaBat 7125 SV, Reson 7125 ROV & $400 \mathrm{kHz}, 200 \mathrm{kHz}$ & NCEI \\
\hline NOAA & $\mathrm{H} 12429$ & 2012 & $\mathrm{MB}$ & Variable Resolution & Seabat 7125-ROV & $400 \mathrm{kHz}$ & NCEI \\
\hline NOAA & $\mathrm{H} 12430$ & 2012 & $\mathrm{MB}$ & 4 & Seabat 7125 & $400 \mathrm{kHz}$ & NCEI \\
\hline NOAA & $\mathrm{H} 12431$ & 2012 & $\mathrm{MB}$ & Variable Resolution & Reson7125 ROV & $400 \mathrm{kHz}$ & NCEI \\
\hline NOAA & H12437 & 2012 & MB & $0.5,2$ & Seabat 7125-ROV & $400 \mathrm{kHz}$ & NCEI \\
\hline NOAA & H12438 & 2012 & MB & 2 & Seabat 7125 & $400 \mathrm{kHz}$ & NCEI \\
\hline NOAA & $\mathrm{H} 12479$ & 2012 & $\mathrm{MB}$ & Variable Resolution & Reson 7125 SV1 & $400 \mathrm{kHz}$ & NCEI \\
\hline NOAA & $\mathrm{H} 12480$ & 2012 & MB & 1,2 & Seabat 7125-ROV & & NCEI \\
\hline NOAA & $\mathrm{H} 12481$ & 2012 & $\mathrm{MB}$ & $0.5,2$ & SeaBat 7125 SV, Reson 7125 ROV & $400 \mathrm{kHz}$ & NCEI \\
\hline NOAA & H12482 & 2013 & MB & Variable Resolution & SeaBat 7125 SV, Reson 7125 ROV & $400 \mathrm{kHz}$ & NCEI \\
\hline NOAA & H12483 & 2013 & $\mathrm{MB}$ & Variable Resolution & SeaBat 7125 SV, Reson 7125 ROV & $400 \mathrm{kHz}$ & NCEI \\
\hline NOAA & H12484 & 2012 & MB & $0.5,2$ & Reson 7125 SV1 & $400 \mathrm{kHz}$ & NCEI \\
\hline NOAA & $\mathrm{H} 12485$ & 2013 & $\mathrm{MB}$ & Variable Resolution & SeaBat 7125 ROV, SeaBat 7125 SV, Reson 7125 & $400 \mathrm{kHz}$ & NCEI \\
\hline NOAA & H12488 & 2012 & MB & $0.5,2$ & Reson 7125 SV1 \& 7125 ROV & $400 \mathrm{kHz}$ & NCEI \\
\hline NOAA & H12489 & 2012 & MB & $0.5,2,4$ & Reson 7125 SV1 \& 7125 ROV & $400 \mathrm{kHz}$ & NCEI \\
\hline NOAA & H12508 & 2014 & $\mathrm{MB}$ & 1,2 & Kongsberg Maritime EM 3002 & $300 \mathrm{kHz}, 400 \mathrm{kHz}$ & NCEI \\
\hline NOAA & H12509 & 2014 & MB & $0.5,1$ & Kongsberg Maritime EM 3002 & $400 \mathrm{kHz}$ & NCEI \\
\hline NOAA & $\mathrm{H} 12510$ & 2014 & MB & $0.5,1$ & Kongsberg Maritime EM 3002 & $300 \mathrm{kHz}, 400 \mathrm{kHz}$ & NCEI \\
\hline NOAA & H12526 & 2013 & MB & $0.5,2$ & SeaBat 7125 SV, Reson 7125 ROV & & NCEI \\
\hline NOAA & H12601 & 2014 & MB & Variable Resolution & R2Sonic 2024 & $540 \mathrm{kHz}$ & NCEI \\
\hline NOAA & H12602 & 2013 & MB & Variable Resolution & R2Sonic 2024 & $540 \mathrm{kHz}$ & NCEI \\
\hline NOAA & H12603 & 2014 & MB & 0.5 & R2Sonic 2024 \& Reson 7125 & $540 \mathrm{kHz}$ & NCEI \\
\hline NOAA & H12608 & 2014 & $\mathrm{MB}$ & $0.5,2,4$ & Kongsberg Maritime EM 3002 & $300 \mathrm{kHz}$ & NCEI \\
\hline NOAA & H12609 & 2015 & $\mathrm{MB}$ & $0.5,4$ & Kongsberg Maritime EM 3002 & $600 \mathrm{kHz}$ & NCEI \\
\hline NOAA & H12610 & 2015 & $\mathrm{MB}$ & $0.5,2$ & Kongsberg Maritime EM 3002 & $300 \mathrm{kHz}$ & NCEI \\
\hline NOAA & H12627 & 2013 & $\mathrm{MB}$ & 2,4 & Reson 7125 & $400 \mathrm{kHz}$ & NCEI \\
\hline NOAA & H12629 & 2013 & MB & 1,2 & Reson 7125 & & NCEI \\
\hline
\end{tabular}


Appendix B: continued

\begin{tabular}{|c|c|c|c|c|c|c|c|}
\hline Agency & Survey & Year & Data Type & Cell Size (m) & System & Frequency & Data Location \\
\hline NOAA & H12676 & 2014 & MB & Variable Resolution & SeaBat 7125 SV, Reson 7125 ROV & $400 \mathrm{kHz}$ & NCEI \\
\hline NOAA & H12677 & 2014 & $\mathrm{MB}$ & $0.5,1$ & Reson 7125 SV1 & $400 \mathrm{kHz}$ & NCEI \\
\hline NOAA & H12678 & 2014 & MB & Variable Resolution & Reson 7125 SV1 \& SV2 & $400 \mathrm{kHz}$ & NCEI \\
\hline NOAA & H12679 & 2014 & MB & Variable Resolution & Reson 7125 SV1 \& SV2 & $400 \mathrm{kHz}$ & NCEI \\
\hline NOAA & $\mathrm{H} 12700$ & 2014 & MB & $1,2,4$ & Reson 7125 & $400 \mathrm{kHz}$ & NCEI \\
\hline NOAA & $\mathrm{H} 12702$ & 2014 & MB & 1,2 & Reson 7125 & $400 \mathrm{kHz}$ & NCEI \\
\hline NOAA & $\mathrm{H} 12707$ & 2014 & MB & $0.5,1,2$ & Reson 7125 & $400 \mathrm{kHz}$ & NCEI \\
\hline NOAA & $\mathrm{H} 12801$ & 2015 & MB & 1,2 & Reson 7125 & $400 \mathrm{kHz}$ & NCEI \\
\hline NOAA & $\mathrm{H} 12802$ & 2015 & MB & $1,2,4$ & Reson 7125 & $400 \mathrm{kHz}$ & NCEI \\
\hline USGS (Alpine Ocean Seismic Survey Inc) & W00294 & 2014 & MB & 1,2 & R2Sonic 2024 & $300 \mathrm{kHz}, 400 \mathrm{kHz}$ & NCEI \\
\hline NOAA & W00318 & 2010 & Interferometric & 4 & Klein Marine Systems System 3000 ***SSS & $100 \mathrm{kHz}$ & NCEI \\
\hline NOAA & W00352 & 2014 & Lidar & 3 & RIEGL VQ-820G Lidar System & & NCEI \\
\hline NOAA & W00405 & 2015 & MB & $1,2,4,8$ & Kongsberg Maritime EM 710, RESON SeaBat 7125 SV & & NCEI \\
\hline NOAA & H12811 & 2015 & MB & $1,2,4$ & Reson 7125 & $400 \mathrm{kHz}$ & NCEI \\
\hline NOAA & H11442 & 2005 & MB & $1,2,4$ & SeaBat 8101 & $455 \mathrm{kHz}$ & NCEI \\
\hline NOAA & H12643 & 2015 & MB & 0.5 & Reson 7125-SV1 \& 7125-SV2 & $400 \mathrm{kHz}$ & NCEI \\
\hline NOAA & H11930 & 2011 & MB & $0.5,1,4$ & Simrad EM3002 & & NCEI \\
\hline NOAA & H11079 & 2004 & MB & 2 & SeaBat 8101 & & NCEI \\
\hline NOAA & H11255 & 2004 & MB & 2 & Simrad EM1002 & & NCEI \\
\hline NOAA & H12462 & 2015 & MB & $0.5,4$ & Reson 7125-SV1 \& 7125-SV2 & $400 \mathrm{kHz}$ & NCEI \\
\hline NOAA & H11998 & 2009 & $\mathrm{MB}$ & 05,4 & Simrad EM3000 & $400 \mathrm{kHz}$ & NCEI \\
\hline
\end{tabular}

